\title{
Hava Gücünün Tarihi Gelişimi: Nitelikler, Bileşenler, Görevler ve Etkinlik Açısından Bir Değerlendirme ${ }^{\star}$
}

\author{
Air Power's Historical Evolution: \\ An Analysis of Properties, Constituent Elements, \\ Missions and Effectiveness
}

\author{
Sitk1 EGELI $\dot{I}^{\star \star}$
}

$\ddot{O} z$

Bu çalışmada, hava gücünün ortaya çıkmasından bu yana geçen 100 ynlı aşkın süre zarfindaki tarihî gelişim sürecinin ikincil kaynaklar kullanan nitel araştırma yaklaşımıyla incelenmesi neticesinde, özellikle Soğuk Savaş sonrası dönemde yayginlk kazanan hava gücünün kara ve deniz güçleri karşısında baskın konuma geçerek artık savaşlarn sonucunu tek başına belirleyebileceği önermesinin sahadaki gelişmelerle çelistiği, zira hava gücünün kullanım sayesinde elde edilen firsatlarn ve avantajlarn taktik, stratejik ve/veya siyas $\hat{\imath}$ sonuçlara dönüştürülebilmesi için satıhta konuşlanmış kuvvet unsurlarna hâlâ ihtiyaç duyulduğu sonucuna ulaşılmıştrr. Varlan bu sonuçla bağlantıl olarak, incelenen dönemde yaşanan süratli teknolojïk gelişmelere rağmen hava gücünün kuvvetli-zaynfyönlerinin ve ifa ettiği görev kategorilerinin ynllar içerisinde büyük oranda aym kaldĭ̆ görülmüstür. Ayrnca, hava gücünün potansiyelinden tam manasıyla yararlamlabilmesinin sadece az sayrda devletin sahip olduğu maddi, teknolojï, örgütsel ve entelektüel kapasitenin kazanılmasın gerekli kildiğ gözlemlenmiştir.

Anahtar Kelimeler: Hava Gücü, Askerî Havacılı, Hava Harbi-Tarih, Harp Tarihi-, Havacılık, Askerî Teknoloji.

\footnotetext{
* $\mathrm{Bu}$ makale, yazarın doktora tezinin ilgili bölümlerinin güncellenmesiyle oluşturulmuştur. Sitkı Egeli, Greek Air Power as a National Security Instrument, Doktora Tezi, Bilkent Üniversitesi, Uluslararası İlişkiler Bölümü, 1998.

${ }^{\star}$ Dr. Öğretim Üyesi, İzmir Ekonomi Üniversitesi, Siyaset Bilimi ve Uluslararası İlişkiler Bölümü, İzmir, Türkiye, ORCID: 0000-0001-6254-1003, e-posta: sitki.egeli@ieu.edu.tr.

Geliş Tarihi / Submitted: 15.06 .2020

Kabul Tarihi / Accepted: 15.08.2020
} 


\section{Abstract}

Using secondary sources and qualitative analysis, this paper has scrutinized the historical evolution of air power since its outset over 100 years ago to reveal that land and naval powers are still required to transform the opportunities and advantages presented by air power into concrete tactical, strategic and/or political outcomes. This finding refutes common propositions since the end of the Cold War contending that air power has now become the dominant form of military power that could singlehandedly determine the outcome of wars. Our historical overview has also illustrated that despite rapid technological progress, air power's strong and weak points, as well as its basic missions have remained unaltered over decades and its successful use and implementation is still dependent on material, technological, organizational, and intellectual assets. This is a demanding list that could be met by a handful of states.

Keyzords: Air Power, Military Aviation, Air Warfare -History, Military History-, Aviation, Military Technology.

\section{Giriş}

Soğuk Savaş'1n sona ermesinden bu yana önce 1991'deki Körfez Savaşı, ardından Balkanlar, Irak ve Libya'da icra edilen hava harekâtları, hava gücünün kara ve deniz kuvvetleri karşısında baskın konuma yükselerek artık savaşların sonucunu tek başına belirleyebilecek olgunluğu ulaştığı iddialarını beraberinde getirmiştir. Suriye'deki iç savaşta Deaş terör örgütünün hava gücü desteğiyle yenilgiye uğratılması, ardından İdlib semalarında İHA'larca (İnsansız Hava Aracı) elde edilen başarılar sayesinde son dönemde bu algının daha da güçlendiğinden bahsedilebilir. Radara görünmeyen uçaklar, akıllı mühimmat, seyir füzeleri ve İHA'lar gibi bileşenleri ileri teknolojiyle özdeşleştirilen hava gücü, en azından geniş kitlelerin gözünde, kendisine verilen her türlü askerî ve siyasî hedefi kolaylıkla ve süratle yerine getirebilecek mucizevî bir savaş vasıtasına dönüşmüştür. Fakat hava gücüne atfedilen yüksek önem ve beklentiler, hava araçlarının icadından bu yana geçen yüz yılı aşkın zaman zarfında hava gücünün içerisinden geçtiği süreçleri, yaşattığı başarısızlık ve hayal kırıklıklarını büyük oranda göz ardı etmekte, dolayısıyla gerek siyasî karar vericilerin gerekse kamuoyunun hava gücünden beklentilerinin hatalı yönlerde ve çok yüksek seviyelerde şekillenmesi tehlikesini beraberinde getirmektedir. Bu konuda daha dengeli ve sahadaki gerçeklerle örtüşen yargılara varılabilmesi için, hava gücünün tabi olduğu siyasî, coğrafî ve hava şartları gibi kısıtların tarihteki tecrübeler ışığında doğru şekilde 
anlaşılmasına ihtiyaç vardır. Benzer şekilde, hava gücünü kullanan veya kullanmayı ümit eden devletlerin ve oyuncuların hangi niteliklerinin hava gücü üzerinde olumlu ya da olumsuz etkilerde bulunabileceğinin irdelenmesi de önem taşımaktadır. Bu türden karşılaştırmalı ve eleştirel çözümlemeler sayesinde, hava gücünden beklentilerin daha gerçekçi bir zemine oturtulması mümkün olabilecek, popüler kültür seviyesinde yaygınlık kazanan ve dijital devrim sayesinde kitlelerin gözünde kesin ve ispatlanmış bilgilermiş gibi muamele görmeye başlayan bazı klişelerin ve genellemelerin doğruluğunun test edilmesi de imkân dâhiline girebilecektir.

$\mathrm{Bu}$ amaçlara yönelik olarak çalışmamızda yanıt aranacak ilk soru, Soğuk Savaş sonrası dönemin çatışmalarında elde ettiği savlanan çarpıcı sonuçlara işaretle, hava gücünün kara ve deniz kuvvetleri karşısında savaşların sonucunu tek başına belirleyebilecek baskın güç unsuruna dönüşüp dönüşmediğidir. İlk soruyla bağlantılı olarak yanıtı aranacak ikinci soru, hava gücü kullanımından başarılı veya başarısız sonuçlar alınmasında etkili olan şartların ve etkenlerin neler olduğudur. Çalışmamızda tarihî gelişim perspektifinde cevaplanmasına çalışılacak üçüncü soru ise, teknolojik gelişme ve sıçramaların hava gücünün temel niteliklerinde, bileşenlerinde ve görev kategorilerinde köklü, kavramsal değişikliklere yol açıp açmadığıdır. Özellikle bu soruya tarihsel gelişim perspektifinde verilecek yanıtın, hava gücünün günümüzde ve yakın gelecekteki kullanımı üzerine bazı çıkarım ve öngörülerde bulunulmasını kolaylaştıracağı değerlendirildiğinden, çalışmanın son kısmında bu nitelikteki içerik ve analizler üzerine yoğunlaşlacaktır. Çalışmada, hava gücünün temel niteliklerinin, bileşenlerinin ve sahadaki performansının tarihi perspektifte, eleştirel ve karşılaştırmalı olarak irdelenmesinde ikincil kaynaklardan yararlanan literatür taramasına dayalı nitel araştırma yaklaşımı kullanılmaktadır.

\section{Hava Gücü - Tanım, Kavramlar Ve Bileşenler}

Hava gücünün yaygın tanımı, yer yüzeyinin üzerindeki üçüncü boyutu kullanan hava vasıtalarının kendileri ve taşıdıkları yükler sayesinde askerî kuvvet aktarımında bulunmalarıdır. Bu yönüyle hava gücünü kara ve deniz gücünden ayıran önemli niteliği, yer yüzeyinin üzerindeki üçüncü boyutun kullanması sayesinde sürat, uzun menzil, esneklik, sakınma ve 
sürpriz gibi avantajların elde edilebilmesidir. ${ }^{1}$ Esasında kara ve deniz gücü unsurlarının ateşlediği mermi ve balistik vasıtalar da üçüncü boyutu kullanmaktadır. Ama hava gücü unsurları bunlardan farklı olarak uçuşları sırasında manevra yapabilme, yön ve irtifa değiştirme ve kendilerini harekâtın değişen şartlarına ve ihtiyaçlarına uyarlayabilme esnekliğini de sunmaktadır. Hava gücünün özelliklerinin, güçlü ve zayıf yönlerinin irdelenmesinde başvurulabilecek bir yaklaşım, yukarıdaki tanımın barındırdığı içeriğin dört alt başlık altında ele alınmasıdır. Bunlar hava gücünün i) nitelikleri, ii) bileşenleri, iii) kullanımına dair özellikler ve iv) kullanım amaçlarıdır. ${ }^{2}$

\subsection{Hava Gücünün Nitelikleri}

Yer sathını terk edemeyen kara ve deniz gücü unsularına kıyasla hava vasıtaları üçüncü boyutu kullanabilmeleri sayesinde önemli bazı avantajlar elde ederler. İrtifanın sağladığı daha geniş görüş ve etki alanı, daha yüksek seyir-intikal sürati, daha uzun menzil, iki yerine üç eksende hareket edebilmenin sağladığ bu avantajlar arasında öne çıkmaktadır. Başka bir ifadeyle, hava vasıtaları yerdeki doğal engellere bağlı kalmaksızın, yer yüzeyindeki herhangi bir noktaya çok daha süratli şekilde kuvvet aktarma potansiyelini bünyelerinde barındırmaktadır. İlaveten hava gücü, kara ve deniz gücünün yapamadığı şekilde rakibin gücünü oluşturan unsurlardan herhangi birini kendisine hedef seçebilmekte, bunu yaparken kendi kara ve deniz unsurlarıla yakın iş birliğine giderek bu ikisinin etkinliğini önemli oranda artırabilmektedir. $\mathrm{Bu}$ yönüyle, hava gücünün özünde yer alan en önemli nitelikler olarak esnekliğin ve çok yönlülüğün yanı sıra, diğer askerî güç unsurlarıyla sinerji yaratan işbirliklerine girebiliyor olmasının altı çizilmelidir. ${ }^{3}$

\subsection{Hava Gücünün Bileşenleri}

Hava gücünün ana bileşenleri olarak, hepsi birbiriyle uyum içerisinde çalışmak zorunda olan hava vasıtaları; onları uçuran, bakımını yapan, sevk ve idaresini gerçekleştiren personel; silahlar ve mühimmat;

\footnotetext{
${ }^{1}$ Peter Gray, Air Warfare: History, Theory and Practice, Bloomsburry, Londra, 2016, p. 2.

${ }^{2}$ Basic Aerospace Doctrine of the United States Air Force, Air Force Manual 1-1, Vol. 1, Department of the Air Force, Vaşington, 1992, p. 1-2.

${ }^{3}$ A.g.e. p. 3-6.
} 
Komuta-Kontrol-Haberleşme ( $\mathrm{C}^{3}$ - Command-Control-Communication) kabiliyeti; bunların tümünün çalışmasını mümkün kılan tesisler ve altyapı ile hava gücünü oluşturan unsurların elde edilmesi ve idamesini sağlayan endüstriyel, teknolojik ve bilimsel imkânlar sayılmalıdır.

$\mathrm{Bu}$ bileşenleri tek tek ele aldığımızda; hava gücünün yıkıcı etkisini hasmın hedeflerine ulaştıran hava vasıtaları arasında ilk sırada, muharip hava unsurları da tabir edilen savaş uçaklarıyla silahlı helikopterler gelmektedir. Keşif, gözetleme, elektronik harp, nakliye, havada yakıt ikmali gibi daha geri planda kalan, ama hava harekâtının başarıya ulaşması için yeri geldiğinde en azından muharip uçaklar kadar önemli roller üstelenebilen diğer hava araçları da bu listeye mutlaka dâhil edilmelidir. Son dönemdeki hava harekâtlarındaki önemi ve görünürlügü süratle artan hem silahlı hem silah taşımayan İHA'lar da artık hava gücünün vazgeçilmez bileşenleri olarak ele alınmayı hak etmektedir. ${ }^{4}$

Hava gücünün en az hava vasıtaları kadar önemli ikinci bileşeni olarak insan gücü ön plana çıkmakta ve hava vasıtalarını uçuran personelden, bunların bakım-idamesini gerçekleştiren yer personelinden ve hava harekâtının sevk ve idaresinden sorumlu yerdeki diğer kadrolardan meydana gelmektedir. Bu bağlamda, kullanılan ekipmanın ve içerdikleri teknolojilerin niteliği ne kadar yüksek olursa olsun, hava gücünün etkin şekilde kullanılıp kullanılamayacağı ve kendinden beklenen sonuçları verip veremeyeceği, o ekipmanı ve teknolojileri kullanan personelin kalitesiyle yakından ilişkilidir. ${ }^{5}$ Etkin hava gücünün gerekli kıldığı nitelik ve nicelikte insan gücünün seçimi, yetiştirilmesi ve muhafazası yıllara, hatta on yıllara yayılan tutarlı, istikrarlı, sistematik ve yüksek maliyetli çabayı ve planlamayı gerektirmektedir.

Hava gücünün üçüncü bileşeni silah ve mühimmattır ve esas itibarıyla hava araçlarınca taşınan silahları kapsamaktadır. Ancak, hasım hava araçlarına karşı kullanılan karada konuşlu silahlar, örneğin satıhtanhavaya füzeler de bu kategoriye dâhil edilmelidir. Zira hava araçlarınca taşınan silah ve mühimmat hava gücünün hedef üzerindeki yıkıcı etkisini

\footnotetext{
${ }^{4}$ Can Kasapoğlu, “Turkey's Drone Blitz Over Idlib”, Terrorism Monitor, https://jamestown.org/ program/turkeys-drone-blitz-over-idlib/ (Erişim Tarihi: 09.06.2020)

${ }^{5}$ Tony Mason, Air Power: A Centennial Appraisal, Brassey's, London, 1994, p. 163.
} 
temsil ederken, satıhta konuşlu hava savunma silahları hava gücünün hasımlar tarafından kullanılmasını engellemeye yönelik unsurlar olarak önem kazanmaktadır.

$\mathrm{C}^{3}$ imkânları, hava gücünün esasında çok temel, ama sıklıkla dikkatlerden kaçan bir diğer bileşenidir. Hava gücünün etkin şekilde kullanılabilmesi ve sunduğu sürat, esneklik ve farklı mecralara uygulanabilirlik avantajlarından layıkıyla yararlanılabilmesi için, hava gücünün tüm bileşenlerinin ihtiyaç duyduğu verilerin, komut ve talimatların hatasız ve eksiksiz üretilerek doğru zamanda, doğru kullanıcılara, doğru formatta ulaştırılabilmesi elzemdir. Hava gücünün üstünlükleri arasında gösterilen yüksek sürat, uzun menzil ve üç eksende hareket edebilme özellikleri, aynı zamanda hava araçlarının tabi olduğu reaksiyon sürelerini kısaltmakta, çok daha hassas ve kapsamlı veriler ile komutların süratle üretilmesini ve tüm kullanıcılara ulaştırılmasını zorunlu kılmaktadır. $\mathrm{Bu}$ zorunluluğu yerine getirilebilmesiyse, ancak yüksek kapasiteli, mükemmele yakın hassasiyet ve güvenilirlikte $\mathrm{C}^{3}$ altyapısının, personelinin ve usullerinin tesis edilmesiyle mümkün olabilmektedir.

Hava gücünün işlevlerini yerine getirebilmesi için hava araçlarının inip kalkabileceği, ikmal, bakım ve onarımlarının yapılabileceği hava üslerine, ayrıca bakım, onarım, depolama gibi faaliyetleri yürütecek tesislere ihtiyaç duyulmaktadır. Saldırılar karşısında yeterli korunmaya, dayanıklılığa ve hızlıca toparlanabilme yeteneğine sahip olması istenen bu tesisler hava gücünün olmazsa olmaz bileşenleridir. İlaveten, hava gücü bileşenlerinin dış kaynaklara bağımlı kalmadan kazanılması ve idamesini mümkün kılacak havacılık ve savunma sanayii imkânlarına sahip olunması ve bu imkânları destekleyecek teknolojik ve bilimsel gelişmişlik seviyesine ulaşılabilmesi de hava gücünün etkin kullanımı açısından önem kazanmaktadır.

\subsection{Hava Gücünün Kullanımına Dair Özellikler}

Esasen her çatışmanın kendine has birtakım şartları ve dinamikleri bulunduğundan, hava gücünün kullanımına yönelik evrensel geçerliliği olan bir formülden bahsedilemez. Zira bir devletin sahip olduğu hava gücü unsurlarının çatışmanın başladığı an itibarıyla fizikî konumu, yapılanması, teçhizatın nitelikleri, hazırlık ve eğitim seviyesi gibi değişkenler, göklerdeki mücadelenin seyri ve sonucu üzerinde etkili olacaktır. Bir ülkenin sahip olduğu hava gücünün niteliklerini ilgilendiren bu değişkenlere 
ilaveten, üç kritik etken daha hava gücünün etkin olarak kullanılıp kullanılamayacağı ve arzu edilen sonuçları verip vermeyeceği üzerinde belirleyici etkiye sahiptir. Bunlar; mücadele edilen rakibin aynı kapsamdaki özelliklerinin durumu, içine girilmekte olan çatışmanın niteliği ve çatışmanın tabi olduğu coğrafi şartlardır. ${ }^{6}$ Rakip gücün özellikleri önemlidir, zira hava gücünün hedefinde yer alan hasmın sıklet merkezleri, nasıl ve hangi etkinlikle savaşabildiği, dolayısıyla hava gücünü etkisiz kılıp kılamayacağı çatışmanın sonucu üzerinde belirleyici olacaktır. Örneğin, kırsal kesimde gerilla taktiklerine başvuran bir hasımla mücadelede kullanılacak hava gücü unsurları ve taktikleri, hava gücünün tüm bileşenlerine sahip bir rakiple girilecek konvansiyonel çatışmanın ihtiyaç göstereceği bileşenlerden ve taktiklerden büyük farklılıklar gösterecektir.

İçine girilen çatışmanın siyasî çerçevesi ve özellikleri de hava gücünün hangi kısıtlar dâhilinde kullanılabileceğini, hangi görev profillerini içerebileceğini ve bunların nasıl fiiliyata aktarılacağını belirleyecektir. Örneğin 1950-1953 yıllarındaki Kore Savaşı'nda, ABD hava gücü Çin Halk Cumhuriyeti topraklarındaki hava üslerini vurarak Kore semalarında süratle hava hâkimiyeti tesis edebilecekken, Sovyetler Birliği'nin Çin'e yönelik böyle bir saldırıya nükleer silahlarla karşılık vermesinden çekinildiğinden, ABD hava saldırıları Kore yarımadası ile sınırlı tutulmuş ve sonuçta hava gücünün potansiyelinden tam manasıyla istifade edilememiştir. ${ }^{7}$

En son olarak hava gücü kullanımı ile coğrafi şartlar arasındaki etkileşim de birçoklarınca kolaylıkla göz ardı edilebilen, ama aslında çatışmanın seyrini ve sonucunu belirleyen önemli etkenlerden birisidir. Bu bağlamda coğrafya sadece arazi şekillerini, bitki örtüsünü, hava şatlarını ve iklimi değil, aynı zamanda cephe hattının genişliğini, harekât alanının derinliğini ve büyüklüğünü, dost hava üslerine olan yakınlığını da içermektedir. Coğrafî kısıtlar bazen hava gücünün kullanım etkinliğinin ötesine geçerek, belli bir rakibe karşı hava gücünün kullanılıp kullanılamayacağını bile belirleyebilmektedir. ${ }^{8} \mathrm{Bu}$ yönüyle coğrafî şartlar

\footnotetext{
${ }^{6}$ Basic Aerospace Doctrine, p. 4-6.

${ }^{7}$ M. J. Armitage ve R. A. Mason, Air Power in the Nuclear Age, University of Illinois Press, Londra, 1983, p. 40-41.

${ }^{8}$ Neville Brown, The Future of Air Power, Croom Helm, London, 1986, p. 17.
} 
hava gücünün bir çatışmadaki rolünü ve etkisini, yürütülecek hava harekâtının türünü, hedeflerini ve görev önceliklerini, hava harekâtının temposunu ve yoğunluğunu belirleyen ana değişkenlerden birisi olarak ele alınmalıdır. Coğrafî şartlar, çatışmanın vuku bulduğu arazi yapısı açısından ele alındığındaysa, örneğin çöller ve düzlükler hava gücünün satıhtaki hedeflere karşı kullanımını kolaylaştırırken, engebeli, dağlık veya ormanlık arazi söz konusu olduğunda havadan karaya angajmanlar güçleşmektedir.

\subsection{Hava Gücünün Kullanım Amaçlan}

Hava gücü temelde, hasım güçler üzerinde yaptırım gücü ve üstünlük sağlamaya, ihtiyaç halindeyse savaşları kazanmaya yönelik bir araçtır. Savaşın siyasetin doğrudan uzantısı olduğunu savlayan Clausewitzçi yaklaşım perspektifinde ele alındığında, hava gücünün bir ulusun siyasî menfaatlerini korumaya yönelik siyasî araçlardan birisi olduğu saptaması yapılabilir. ${ }^{9}$ Bu yönüyle, hava gücünün etkin kullanımı her ne kadar harp ve askerlik sanatı kaidelerinin doğru şekilde uygulanmasına bağlı olsa da, sonuçta hava gücünün sahaya sürülmesi ulusal çıkarlara hizmet etmeli ve ulusal gücün askerî olmayan enstrümanlarıyla uyum ve eşgüdüm içerisinde kullanılabilmelidir. Başka bir ifadeyle, hava gücünün bir çatışmada ürettiği sonuçlar askerî ve taktik seviyede ne denli başarılı olursa olsun, eğer bu sonuçlar ulusal çıkarlara ve hedeflere hizmet etmiyorsa, hava gücünün kendinden beklenen faydayı sağlamadığından, hatta ulusal kaynakların israf edilmesi sonucunu doğurduğundan bahsedilebilir.

Hava gücü taktik ve operasyonel seviyedeki hedefleri itibarıyla ele alındığındaysa, öncelikle rakibin hava gücünü oluşturan bileşenler (hava araçları, satıhta konuşlu hava savunma sistemleri, hava üsleri, komuta-kontrol ağı, destekleyici altyapı vb.) gelmekte; bunları karşı tarafın karada ve denizdeki kuvvet unsurları takip etmektedir. Savaşın niteliğine ve şatlarına bağlı olarak, askerî olmayan ama savaş faaliyetinin sürdürülebilirliği açısından stratejik önemdeki diğer altyapı tesisleri (enerji üretim-dağıtımı, haberleşme, ulaşım, sanayi ve özellikle havacılık-savunma sanayii tesisleri vb.), hatta kimi savaşlarda sivil halkın kendisi de hava gücünün hedefleri arasında yer alabilmektedir.

${ }^{9}$ Carl Von Clausewitz, On War, (Çev. Michael Howard and Peter Paret), Princeton UP, 8th edition, Princeton, 1984, p. 87. 
Hava Gücünün Tarihi Gelişimi: Nitelikler, Bileşenler, Görevler ve Etkinlik Açısından Bir Değerlendirme

\section{Hava Gücünün Ve Görevlerinin Tarihsel Gelişimi}

Gökyüzünün askerî amaçlarla kullanımına yönelik emeller uçma fikrinin kendisi kadar eskiye dayanmakla birlikte, bunun mümkün kılan teknolojik gelişme 1783 yılında sıcak hava balonuyla geçekleştirilen ilk sürdürülebilir insanlı uçuş olmuş, takip eden on yıllarda o zamanki adıyla "uçan küreler" muharebe alanlarının gözetlenmesinde kullanılmıştır. ${ }^{10}$ Yaklaşık bir asır sonra, yani 19. yüzyılın son çeyreğine girildiğinde, sıcak hava balonlarının yerini artık manevra yapabilen hava gemilerinin almaya başlamış ve hava araçlarının cephe hattının ve coğrafî engellerin üzerinden aşarak düşman ülkesinin derinliklerini havadan vurmakta kullanılabileceği fikri şekillenmeye başlamıştır. Bu yıllarda, İngiliz Ordusu'nda görevli bir istihkâm binbaşısı, askerî havacılı̆̆ın harbin doğası ve yapılış tarzı üzerindeki etkilerinin barutun icadından bile derin olacağını öne sürmüştür. Fullerton isimli bu binbaşı, gelecekteki savaşların açılışının havadaki büyük muharebelerle gerçekleşeceği, savaşın sonucunu belirleyeninse taraflardan birisine ait hava filosunun diğer tarafın başkenti üzerine ulaşması olacağ 1 öngörüsünde bulunmuştur. ${ }^{11}$

Askerî havacılığın gelişimi açısından gerçek manada dönüm noktası teşkil eden ve 'hava gücü' kavramının ortaya çıkmasına önayak olan teknolojik sıçrama, 1905 yılında Wright kardeşlerin "havadan ağır” bir hava aracıyla ilk sürdürülebilir insanlı uçuşu gerçekleştirmesiyle gelmiştir. 1905'ten Birinci Dünya Savaşı'nın patlak verdiği 1914'e kadar geçen dönem, devrin başat güçlerinin Wright kardeşlerin ilkel uçağından daha güvenilir ve daha yüksek performanslı hava makineleri geliştirerek bunların askerî amaçlarla kullanılma rekabetine sahne olmuştur. Hatta 1911-1912'deki Trablusgarp (Türk-İtalyan) Savaşı sırasında uçaklar önce keşif, savaşın ilerleyen evrelerindeyse çok ilkel şartlarda da olsa yer hedeflerine taarruzda kullanılmıştır. ${ }^{12}$ Ancak, bazı İtalyan uçaklarının yerden açılan ateşle

${ }^{10}$ John Guttman, Reconnaissance and Bomber Aircraft Aces of World War 1, Osprey, Londra, 2015, p. 6.

${ }^{11}$ J.D. Fullerton, Some Remarks on Aerial Warfare, U.S. Congress Senate Executive Document 119, 1894, p. 571-574'e atıf yapilan A. F. Hurley, Billy Mitchell: Crusader for Air Power, Indiana UP, Bloomington, 1975, p. 142.

12 "Experience of Air Power in Libya", Pathfinder, http://airpower.airforce.gov.au/APDC/ media/PDF-Files/Pathfinder/PF152-The-Experience-of-Air-Power-in-Libya.pdf (Erişim 
düşürülmesi, uçan makinelerin sadece yüksek potansiyellerini değil, aynı zamanda kırılganlıklarını da gözler önüne sermiştir. Tecrübeyle fark edilen kısıtlar arasında sadece uçakların kırılganlığı değil, aynı zamanda hava gücünün etkin kullanımının olmazsa olmazı niteliğindeki güvenilir ekipman, eğitimli personel, lojistik altyapı, askerî havacıllğın özel şartlarına uygun örgütlenme ve tüm bunları elde tutmanın güçlükleri yer almaktadır.

\subsection{Birinci Dünya Savaşı}

Beklenebileceği üzere, 1914-1918 yılları arasındaki Birinci Dünya Savaşı bir yandan uçakların ve hava gemilerinin geniş çaplı kullanımına sahne olurken, diğer taraftan da hava gücünün daha etkin kullanımı için gerekli olan tekniklerin, taktiklerin ve teçhizatın çoğu kez deneme-yanılma yoluyla geliştirilmesine vesile teşkil etmiştir. Bu manada, Birinci Dünya Savaşı sırasında birbirinden ayrışmaya başlayan hava gücünün farklı görev kategorileri, bundan yirmi yıl sonra İkinci Dünya Savaşı'nda çok daha gelişmiş araçlar ve teknolojilerle icra edilecek görev ve harekât türlerinin temellerini atmıştır. Bu kapsamda, Birinci Dünya Savaşı'nın erken evrelerinde uçaklarca üstlenilen ilk ve asli görev, denemeleri birkaç yıl önce İtalyanlarca Libya'da yapılmış olan "havadan keşif" görevi olmuştur. Savaşın akışı içerisinde havadan keşif görevi, havadan görüntü alınması ve topçu ateş tanzimi gibi yeni teknikler ve kullanım şekilleriyle zenginleşmiştir. ${ }^{13}$

Hava gücünün Birinci Dünya Savaşı'nın akışı içerisinde şekillenen ikinci kullanım şekli, aslında öngörüsü 19. Yüzyılda yapılmış olan ve rakibin cephe hattının gerisindeki çoğu kez doğrudan askerî nitelik taşımayan hedeflerine yönelik uzun menzilli bombardıman görevidir. Düşmanın savaşa devam etme kapasitesini ister maddi ister manevi açıdan çökertmeye yönelik bu harekât türü, doğrudan cephe hattını ilgilendiren "taktik" değerlendirmelerin ötesine geçerek cephe hattının gerisine ve düşmanın ülkesinin derinliklerine sirayet etmesine istinaden, "stratejik bombardıman” görevi olarak adlandırılmıştır. Birinci Dünya Savaşı'nın sınırlı tecrübeleri, bu kullanım tarzının sivil halk üzerinde ilk etapta

Tarihi: 09.06.2020).

13 Timothy Garden, "The Air-Land Battle", R. A. Mason, (ed.), War in the Third Dimension: Essays in Contemporary Air Power, Brassey's, Londra, 1986, 149-167, p. 159. 
şok etkisi yaratsa da, bu etkinin kalıcı olmadığı ve kısa süre içerisinde geri teperek halkın savaşma isteğini ve direncini daha da artırabildiğini ortaya koymuştur. ${ }^{14}$

Hava gücünün Birinci Dünya Savaşı sırasında belirginleşen üçüncü kullanım şekli olan taktik harekâtlar ise, uzun vadede sonuç almaya yönelik stratejik bombardıman yerine, doğrudan cephe hattındaki çatışmaların seyrini ve sonucunu etkilemeye yöneliktir. Savaşın sonlarına doğru görece yüksek performanslı uçakların ve yer taarruz taktiklerinin devreye girmesiyle, düşmanın cephe hattındaki ve hemen gerisindeki kuvvetlerinin havadan ateş altına alınarak imha edilmesi veya dağıtılması mümkün olmaya başlamıştır. ${ }^{15} \mathrm{Bu}$ arada, hava gücünün satıhtaki çatışmalara yönelik kullanımı sadece karadaki hedeflerle sınırlı kalmamıştır. Denizdeki hedeflerin tespitinde büyük avantaja sahip olduğu anlaşılan uçaklar, satıhtaki gemilerin ve deniz sathının altındaki denizaltıların ve mayınların tespitinde yaygın olarak kullanım bulmuştur. ${ }^{16}$ Hava gücünün taktik kullanımı altındaki "taktik nakliye" görevinin, yani cephedeki kara birliklerinin havadan ikmali ve takviyesinin mütevazı örneklerine de Birinci Dünya Savaşı'nda rastlanmıştır. ${ }^{17}$

Hava gücünün satıhtaki savaşın seyrini değiştirme potansiyelinin fark edilmesiyle, özellikle Batı Avrupa semalarında kontrolün ele geçirilmesine ve düşman uçaklarına kullandırılmamasına yönelik çok büyük çapli, hatta abartılı ve amacından sapmış yoğunlukta bir hava mücadelesi yaşanmıştır. Savaşın kapanış evrelerine doğru aynı anda düzinelerce, bazen yüzlerce uçağın havada karşılaşmasına ve birbirleriyle ölümcül düellolara girişmesine tanıklık eden göklerdeki bu mücadele sayesinde, "hava hâkimiyeti" ve "hava üstünlügü” adlarıyla anılan iki görev kategorisi şekillenmiştir. Hava hâkimiyeti, rakibin gökyüzünü kullanmasının tamamıyla engellendiği, bu sayede dost hava unsurlarının görevlerini en etkin şekilde icra edebildikleri durumu tanımlamaktadır. Hava üstünlüğü ise belirli bir bölge üzerinde belli bir zaman diliminde üstünlük sağlanmasını amaçlamakta, bu yönüyle

${ }^{14}$ Robin Higham, One Hundred Years of Air Power and Aviation, Texas A\&M UP, College Station, 2003, p. 18.

${ }^{15}$ Robin Higham, Air Power: A Concise History, St.Martin's Press, New York, 1972, p. 41-43.

${ }^{16}$ Tim Benbow, British Naval Aviation: The First 100 Years, Ashgate, Surrey, 2011, p. 26-54.

${ }^{17}$ Higham, Concise History, p. 41. 
daha mütevazı ve kolay ulaşılabilir bir hedefe işaret etmektedir. ${ }^{18}$ Birinci Dünya Savaşı'nda gökyüzünde elde edilen avantajın satıhtaki savaşa yansıtılamadığı sürece tek başına fazlaca anlam taşımayacağı, ayrıca insan gücü ve malzeme bakımından son derece maliyetli olacağı süratle fark edilmiştir. Dolayısıyla, hava hâkimiyetinden ziyade, ihtiyaç duyulduğu anda ve yerde hava üstünlügüünün elde edilmesi gökyüzündeki üstünlük mücadelesinin daha gerçekçi hedefi haline gelmiştir. ${ }^{19}$

Sonuç itibarıyla, Birinci Dünya Savaşı'nda hava gücü satıhtaki savaşın seyrini ve sonucunu belirleyebilecek etkinlikten uzak kalmış olsa $\mathrm{da}$, elde edilen tecrübeler sayesinde hava gücünün kuvvetli ve zayıf yönleri anlaşılmaya başlanmıştır. Bu kapsamda uçakların kuvvetli yönleri arasında sürat, sürpriz etkisi, esneklik ve coğrafi engellerden bağımsız harekât yapılabilme bulunurken; zayıf yönler arasındaysa gelişmiş altyapı unsurlarına ihtiyaç göstermeleri, yerdeyken saldırıya son derece açık olmaları, havada kalış sürelerinin yetersizliği, geceleri ve olumsuz hava koşullarında etkinliklerini kaybetmeleri sayılabilir. ${ }^{20}$

\section{2. İki Savaş Arası Dönem}

Birinci Dünya Savaşı'nı takip eden yirmi yıllık dönem, önemini ve potansiyelini yoğun savaş ortamı sayesinde ispatlamış hava gücü açısından sıkıntılı bir zaman dilimidir. Dönemin havacıları, bir yandan savaşın sona ermesiyle askerî havacılık alanında yeni yatırım yapılmasına ihtiyaç kalmadığı algısıyla mücadele ederken, diğer yandan da silahlı kuvvetlerin teşkilatlanması ve kültürü üzerindeki kontrolünü sürdüren kara ve deniz kuvvetleri karşısında rüştlerini ispat etmeye çalışmışlardır. ${ }^{21} \mathrm{Bu}$ mücadelede hava gücünün önemini savunanların saptığı kestirme, fakat aslında Birinci Dünya Savaşı'nın tecrübeleriyle örtüşmeyen yollardan birisi, stratejik hava bombardımanı sayesinde gelecekteki savaşların süratle ve büyük insan kayıplarına gerek kalmadan sona erdirilebileceği iddiası olmuştur. Öncelikle Douhet, ama aynı zamanda Mitchell, Seversky ve Sykes

\footnotetext{
${ }^{18}$ Armitage, Nuclear Age, p. 4.

${ }^{19}$ Robin Higham, Military Intellectuals in Britain 1918-1939, Rutgers, New Brunswick, 1966, p. 253-256.

${ }^{20}$ Martin Van Creveld, Technology and Warfare, Brassey's, Londra, 1991, p. 188.

${ }^{21}$ Örneğin bkz. Guilio Douhet, The Command of the Air, (Çev. Dina Ferrari), Air UP, Alabama, 2010, p. 4-5, 28-30.
} 
Hava Gücünün Tarihi Gelişimi: Nitelikler, Bileşenler, Görevler ve Etkinlik Açısından Bir Değerlendirme

gibi dönemin hava gücü vizyonerlerince hararetle savunulan bu görüş, ${ }^{22}$ başta İngiltere ve İtalya olmak üzere bazı devletlerin iki savaş arası dönemde hava güçlerini stratejik bombardıman taktikleri ve filoları etrafında şekillendirmesi sonucunu doğurmuştur. ${ }^{23}$

Diğer taraftan, Birinci Dünya Savaşı'nın kaybedenleri arasında yer alan Sovyetler Birliği ve özellikle de Almanya'daki askerî planlamacılar, uçakları artık süratle mekanize olmaya başlayan kara kuvvetlerinin doğrudan bir destekleyicisi ve tamamlayıcısı olarak görmüştür. Dolayısıyla, görece kısıtlı maddi ve endüstriyel imkânlarını hava gücünün taktik boyutuna, yani süratle ilerlemekte olan mekanize kara birliklerinin hemen önündeki hedefleri vurabilecek tipteki uçaklara ve taktiklere yönlendirmişlerdir. ${ }^{24}$ Hem Almanya ve Sovyetler Birliği, hem de Uzakdoğu'nun yükselen gücü Japonya açısından iki savaş arasındaki dönemin talihli bir gelişmesi, hava gücünün bu türden taktik kullanımının denenebildiği ve mükemmelleştirilebildiği İspanya ve Çin'deki sınırlı savaşlara iştirak etmeleri olmuştur. ${ }^{25}$ Hava gücünün "stratejik" saldırılar için kullanılmasına öngören hava kuvvetleriyle, uçakları karadaki savaşın "taktik" destekleyicisi olarak gören hava kuvvetleri arasındaki ayrışma İkinci Dünya Savaşı'nın başladığı 1939'a kadar, hatta savaşın ortalarına kadar devam etmiştir. Bundan kısa süre sonra sahada yaşanacak gelişmeler, stratejik bombardıman uçakları henüz düşmanın savaşma azmini ve kapasitesini yok etmeye firsat bulamadan, taktik hava gücünün cephedeki dengeyi dost kara birlikleri lehine çevirerek savaşı sona erdirebildiğini ispatlayacaktır. ${ }^{26}$

\footnotetext{
${ }^{22}$ William Mitchell, Winged Defense, University of Alabama, Tuscaloosa, 2005, p. 8-9; Douhet, Command of Air, p. 26-34; Edward Warner, "Douhet, Mitchell, Seversky: Theories of Air Warfare", Edward M. Earl (ed.), Makers of Modern Strategy, Princeton UP, 1943, 485-503, p. 485-503; David Gates, Sky Wars: A History of Military Aerospace Power, Reaktion, Londra, 2003, p. 26-30.

${ }^{23}$ John Gooch, "Introduction", John Gooch, (ed.), Air Power: Theory and Practice, Frank Cass, Londra, 1995, 1-6, p. 2.

${ }^{24}$ Bernard Brodie, "Some notes on the evolution of air doctrine", World Politics, 1955, Cilt 7, Sayı 3, 349-370, 1955, p. 352.

${ }^{25}$ James S. Corum, "The Luftwaffe and Lessons Learned in the Spanish Civil War", Sebastian Cox ve Peter Gray (ed.), Air Power History: Turning Points from Kitty Hawk to Kosovo, Frank Cass, Londra, 2002, 66-92, p. 77-78.

${ }^{26}$ Higham, Concise History, p. 87.
} 
İki savaş arası dönemde hava gücünün evrimi açısından mutlaka değinilmesi gereken bir diğer önemli husus, teknik ve teknolojik alandaki hızlı gelişmeler sayesinde, uçakların performansında ve güvenilirliğinde büyük sıçramaların yaşanması ve Birinci Dünya Savaşı'na kıyasla hava gücünün her boyuttaki etkinliğinin bariz olarak artmasıdır. Uçakların süratlerinde, uçabildikleri mesafede ve taşıyabildikleri silah yükünde kaydedilen büyük artışlara ilaveten, özellikle elektronik sanayiinde yaşanan gelişmeler sayesinde uçaklara telsiz cihazları takılmasının sağladığ avantajlara mutlaka değinilmelidir. Zira, havadaki uçakların birbirleriyle ve yerdeki dost kuvvetlerle haberleşmesine imkânı tanıyan telsiz cihazı olmasa, hava gücünün taktik sahada başarılı kullanımından bahsedilmesi mümkün olmazdı. Dolayısıyla, Birinci Dünya Savaşı'ndan İkinci Dünya Savaşı'na kadar geçen yirmi yıllık zaman diliminde hava gücünün daha etkin kullanımını mümkün kılan etkenlerden birisi olarak süratli teknolojik gelişimin altı çizilmelidir.

\section{3. İkinci Dünya Savaşı}

1939 yılında Almanya'nın Polonya'ya saldırmasıyla patlak veren ve bütün Dünya'ya yayılan savaş, hava gücünü diğer kuvvetlerin tamamlayıcısı ve destekleyici olmaktan çıkarıp, kendi başına ve bağımsız bir kuvvet statüsüne kavuşturmuştur. Savaşın ilk günlerinde Alman hava kuvvetleri "karşı hava harekâtı" adıyla anılan görev türüne öncelik vererek Polonya'nın hava meydanlarını süratle devre dışı bırakmış, havadaki kontrolün ele geçirilmesiyle Alman uçakları karadaki birliklerle yakın iş birliğine girerek, bu birliklere istenen yerde, istenen zamanda ateş desteği sağlayan hareketli topçu silahlarına dönüşmüştür. "Yakın hava desteği” adı verilen hava gücünün bu yeni taktik kullanım şekli, zırhlı birliklerin mobilite ve yüksek ateş gücü avantajının uçaklarca verilen destek sayesinde daha da yükseltilmesine imkân tanıyarak, Yıldırım Savaşı (Blitzkrieg) adıyla anılan çı̆̆ır açıcı nitelikteki harp türünü şekillendirmiştir. ${ }^{27}$ Yıldırım Savaşı tabiri genelde Almanya'nın 1939-1941 dönemindeki harekâtlarıyla ilişkilendirilse de, hava gücü ile satıhtaki birlikler arasında yakın eşgüdüm ve iş birliğini gerektiren bu yeni taktik hiç vakit kaybetmeden Almanya'nın rakiplerince de benimsenmiştir. Önce Kuzey Afrika'da, ardından 1944'teki

\footnotetext{
${ }^{27}$ Bryan Perret, A History of Blitzkrieg, Robert Hale, Londra, 1983, p. 69-76.
} 
Normandiya çıkarmasını takip eden kara muharebelerinde yakın hava desteği ABD ve İngiliz hava kuvvetlerince mükemmelleştirilmekle kalmamış, aynı zamanda "hava tecridi" adı verilen ve cephe hattındaki düşman birliklerinin tecrit edilmesin, hedefleyen yeni bir görev kategorisini de içine alacak şekilde genişletilmiştir. ${ }^{28}$

Hava gücünün "taktik" kullanımıyla elde edilen olumlu sonuçların tersine, İkinci Dünya Savaşı'nda hava gücünün “stratejik” kullanımı çoğu kez hayal kırıklığı ile sonuçlanmıştır. 1940 yılındaki Britanya (hava) Muharebesi sırasında Alman bombardıman uçaklarının İngiliz şehirlerine yönelik saldırılarının İngiliz halkının savaşma direncini kırmakta başarısız olduğunun görülmesine rağmen, hem İngiltere hem ABD savaşın takip eden yıllarında aynı anda birkaç bin ağır bombardıman uçağının katıldığı stratejik hava taarruzlarıyla Almanya'yı dize getirmeye çalışmıştır. ${ }^{29} \mathrm{Hem}$ malzeme, hem insan gücü açısından son derece yüksek maliyetli bu saldırıların Almanya'nın yenilgiye uğratılmasında ne derece etkili olduğuna dair tartışmalar günümüze kadar devam etmiştir. Konunun önde gelen araştırmacıları arasında, stratejik bombardıman için harcanan kaynakların karşılığının alınamadığı saptaması daha yaygın kabul görmektedir. ${ }^{30}$

$\mathrm{Bu}$ arada, stratejik bombardıman açısından savaşın ağırlık merkezi Avrupa semaları olmakla birlikte, Asya-Pasifik cephesinde Japonya da Amerikan bombardıman uçaklarının saldırılarından payına düşeni almıştır. Fakat ABD hava bombardımanının Japonya üzerinde oluşturduğu onca yıkıma rağmen, Japon hükümeti ve halkının direnme azminde hiçbir azalma görülmemiş, bunun gerçekleşmesi için iki Japon şehrinin ağır bombardıman uçaklarınca hedefe ulaştırılan atom bombalarıyla vurulması gerekmiştir. Akabinde, Japonya'nın birkaç gün içerisinde kayıtsız şartsız

\footnotetext{
${ }^{28}$ Robert H. George, “Normandy”, Wesley F. Craven ve James L. Cate (eds.), The Army Air Forces in World War II, Volume 3: Europe, University of Chicago Press, Chicago, 1951, 183-227, p. 209-219.

${ }^{29}$ A. P. N. Lambert, The Psychology of Air Power, RUSI, Londra, 1995, p. 18-19.

${ }^{30} \mathrm{Bu}$ görüsün aksettirildiği akademik literatüre örnek olarak bkz. Tami Davis Biddle "British and American Approaches to Strategic Bombing", John Gooch (ed.), Air Power: Theory and Practice, Frank Cass, Londra, 1995, 91-144, p. 128-129.
} 
teslim olmayı kabul etmesi, esasında hava gücünden ziyade savaşa ait tüm ezberleri bozan nükleer silahların icadının bir sonucu olarak görülmelidir. ${ }^{31}$

İkinci Dünya Savaşı'nda hava gücünün potansiyelinin ispatlandığı iki görev sahası daha vardır. Bunlar, denizdeki savaşa havadan verilen destek ile uçaklarca ifa edilen taktik nakliye görevidir. Öncelikle savaşın denizdeki çatışmalar boyutuna değinmek gerekirse, Atlantik Okyanusu'ndaki deniz ulaşımını durdurmaya çalışan Alman denizaltılarının \%60'nın, Alman ve İtalyan donanmalarına ait satıh gemilerinin ise neredeyse tamamının savaş uçaklarınca batırılmış olduğu gerçeği, hava gücünün deniz savaşları üzerindeki belirleyici rolünü ispatlamıştır. Benzer şekilde Pasifik cephesindeki hava saldırıları, özellikle büyük tonajlı savaş gemilerinin hava gücü karşısındaki savunmasızlığını ve kırılganlığını gözler önüne sermiş, savaşın seyri süratle iki tarafın uçak gemileri ve taşıdıkları uçaklar arasındaki üstünlük mücadelesine dönüşmüştür. ${ }^{32}$

İkinci Dünya Savaşı'nda hava gücünün icra ettiği taktik nakliye görevi kapsamındaysa, coğrafya veya düşmanca tecrit edilmiş kara birliklerinin havadan takviye edildiklerinde savaşmayı sürdürebildikleri görülmüştür. Buna karşılık, Almanya'nın Stalingrad kuşatmasında yaşadığ felaket, bu kullanım tarzında hava gücünden beklentilerin makul ve gerçekçi seviyelerde olması gerektiğine işaret etmektedir. Havadan taktik nakliye görevinin bir diğer kullanım alanı, düşman topraklarına hava indirme birlikleri, yani paraşütçülerin indirilmesi olmuştur. Almanya'nın Norveç ve Girit'i ele geçirmekte kullandığı paraşütçü birlikleri, özellikle uzak, tecrit edilmiş ve/veya düşmanca kolaylıkla takviye edilemeyecek bölgelerde başarıya ulaşmıştır. Buna karşılık, düşmanın cephe hattının gerisindeki kritik noktalara paraşütçülerin indirilmesi suretiyle dost birliklerin ilerleyişinin hızlandırılması girişimlerden daha belirsiz sonuçlar alınmıştır. Örneğin, 1944'te Müttefikler'in Arnhem-Belçika'da gerçekleştirdikleri tarihin en büyük hava indirme harekâtı fiyaskoyla sonuçlanmıştır. ${ }^{33}$

\footnotetext{
${ }^{31}$ Brodie, Air Doctrine, p. 363-366.

${ }^{32}$ Higham, Concise History, p. 147-191.

${ }^{33}$ Roy M. Stanley, Evolution of Airborne Operations, 1939-1945, Penn \& Sword, e-kitap, 2015, p. 250-253.
} 
Hava Gücünün Tarihi Gelişimi: Nitelikler, Bileşenler, Görevler ve Etkinlik Açısından Bir Değerlendirme

\subsection{Soğuk Savas Yilları}

İkinci Dünya Savaşı'nın sona ermesini takip eden dönemde Dünya kendini Sovyetler Birliği ile ABD'nin başını çektiği Doğu ve Batı blokları arasındaki yeni bir rekabet ve gerginlik ortamının içerisinde bulmuştur. Soğuk Savaş adıyla anılan bu mücadelenin ilk evrelerinde ağır bombardıman uçakları, nükleer silahları hedefe ulaştırabilecek tek platform türü olarak nükleer dehşet dengesinde kritik rol üstlenmişlerdir. Takip eden dönemlerde bu görevin ifasında ağırlığın önce karada, sonra denizaltında konuşlu balistik füzelere kaymasına rağmen, muharip uçaklar günümüze kadar nükleer silaha sahip devletler için nükleer sacayağının (triad) vazgeçilmez unsurları olmaya devam etmiştir. ${ }^{34}$

Diğer taraftan, bloklararası mücadelenin askerî alandaki ilk sürtüşmesi olarak nitelenebilecek Berlin ablukasında, milyonlarca insanın yaşadığ büyük bir kentin tüm ihtiyaçları ABD'nin kurduğu büyük ölçekli hava köprüsüyle iki yıl boyunca havadan taşınmıştır. Böylece Soğuk Savaş'ın henüz aç1lış evresinde, hava gücünün rolünün sadece nükleer silahların hedefe ulaştırmasıyla sınırlı kalmayacağı, taktik senaryoları da içereceği görülmüştür. Nitekim, Soğuk Savaş’ın ilk büyük çaplı askerî çatışması olan Kore Savaşı'nda, ABD'nin Japonya'da konuşlanmış uçakları hava gücünün esnekliğini ve denizaşırı güç aktarım potansiyelini ortaya koyarak Kuzey Kore'nin ilerleyişini yavaşlatmışlar ve kara birliklerinin Kore yarımadasına intikali için hayati önemdeki zamanı yaratmışlardır. $\mathrm{ABD}$ hava gücünün Kore yarımadası üzerindeki hava hâkimiyetini kolaylıkla elde etmesi ve yerdeki çatışmalara sınırsız destek sağlamasıyla, karada ibre süratle Güney Kore ve ABD önderliğindeki Birleşmiş Milletler kuvvetleri lehine dönmüştür. Ancak Çin Halk Cumhuriyeti'nin müdahil olmasıyla karadaki savaş durağan ve her iki taraf açısından yüksek maliyetli bir nitelik kazanırken, hava gücünün karadaki bu türden bir yıpratma savaşının seyrini ve sonucunu değiştirebilecek etkiyi yaratmakta yetersiz kaldığ görülmüsstür. ABD'nin hava, deniz, deniz piyade ve kara kuvvetleri bünyesindeki birbirinden bağımsız hava gücü unsurları arasındaki eşgüdümün kurulamamasının, ilaveten savaşı yöneten komuta kademesinin

${ }^{34}$ Darius E. Watson, "Rethinking the US Nuclear Triad”, Strategic Studies Quarterly, 2017, Cilt 11, Say1 4, 134-150, p. 134-135. 
hava gücüne yabancılığının bu sonucun ortaya çıkmasında etkili olduğu iddia edilmiştir. ${ }^{35} \mathrm{Bu}$ arada, ABD’nin Sovyetlerin nükleer silahlarla karşılık vermesinden çekinerek Çin topraklarındaki hava üslerini vurmaktan imtina etmesi, Çin savaş uçaklarının Kore semalarında boy göstererek ABD'nin hava hâkimiyetini delmesi sonucunu doğurmuş, böylece Kore Savaşı hava gücünün siyasî kısıtlamalara tabi kılındığı klasik bir örnek olarak tarihteki yerini almıştır. Sonuç olarak Kore Savaşı, hava gücünün İkinci Dünya Savaşı'nda zaten tanımlanmış görevlerine bir katkıda bulunmadığı gibi, uçakların tek başlarına savaş kazandıramayacağı saptamasını teyit etmiştir. ${ }^{36}$

Soğuk Savaş, iki süper güç arasındaki arası gerginlik ve rekabete ilaveten, Avrupa'nın önde gelen devletlerinin denizaşırı topraklarını ve sömürgelerini elde tutabilmek için hava gücüne başvurmalarına da tanıklık etmiştir. 1945 yılından itibaren İngiltere, Fransa ve Portekiz sömürgelerindeki ayaklanmaları ve silahlı direnişi bastırabilmek için hava kuvvetlerine başvurmuşlardır. Ancak, düzenli ordu niteliği taşımayan ve genelde gerilla harbi taktiklerine başvuran ve/veya kentsel alanlarda terörist saldırılar gerçekleştiren rakipler karşısında hava gücünün fazlaca etkisinin olmadığı, bunun yerine esas mücadelenin karada verilmesinin gerektiği kısa sürede anlaşılmıştır. Çünkü hava gücü tespit veya teşhis edemediği hedefler üzerinde ateş gücünü yoğunlaştıramadığı gibi, hava gücünün bu şekilde kullanımının çoğu kez ters teperek sivil halkı karşı tarafın kollarına itebildiği görülmüştür. ${ }^{37}$ İngiltere ve Fransa'nın özellikle Hindiçin'de edindiği tecrübeler, "isyan bastırma" (counter-insurgency - COIN) olarak adlandırılan bu harekât türünde hava gücünce sağlanan desteğin önemini ortaya koymakla birlikte, aynı zamanda sonuca yönelik eylemlerin karadaki unsurlarca gerçekleştirilmesinin gerekliliğine işaret etmektedir. ${ }^{38}$

Kazandığ1 tecrübelerden gereken dersleri çıkaramayan Fransa, Hindiçin'nden 1954'te çekilmek zorunda kalmıştır. Aradan on yıl geçmeden, bu kez Dünya'nın en gelişmiş hava gücüne sahip ABD, üstelik aynı

\footnotetext{
${ }^{35}$ Alan Stephens, “The Air War in Korea”, John A. Olsen (ed.), A history of air warfare, Potomac Books, Vaşington, 2010, 85-106, p. 88-89.

${ }^{36}$ Van Creveld, Technology and Warfare, p. 276.

37 Richard L. Clutterbuck, The Long, Long War: Counter-insurgency in Malaya and Vietnam, Cassell, Londra, 1967, p. 160-161.

${ }^{38}$ Armitage, Nuclear Age, p. 68-69.
} 
topraklarda ve aynı düşmana karşı benzer hataları tekrarlayarak aynı kaderi paylaşmıştır. Bu kapsamda, ABD'nin 1960'lı yıllar boyunca Vietnam'da aşamalı olarak tırmanan askerî varlı̆̆ı ve harekâtları önemli bir hava gücü bileşeni içermiştir. Zira Vaşington'daki karar vericiler, hava gücünün Amerikalı askerlerin hayatını tehlikeye atmadan karadaki savaşı kendi lehlerine çevirebileceği beklentisi ve yanılgısı içinde olmuşlardır. Hava gücü kendinden beklenenleri vermedikçe ve savaş uzadıkça, ABD'nin Vietnam'daki hava gücü kullanımının arttığı, ama arzu edilen sonuçların bir türlü elde edilemediği kısır bir döngü içerisine girilmiştir. Sonuçta $\mathrm{ABD}$ teknoloji ve malzeme alanlarındaki ezici üstünlüğüne rağmen, rakibinin gerilla ve gayrinizami harp taktikleri karşısında yenilgiye uğrayarak Vietnam'dan apar topar çekilmek zorunda kalmış ve yaşanan hezimet hava gücünün başarısızlığ

Uçakların savaşın sonucunu belirleyememiş olması bir yana, aslında Vietnam Savaşı hava gücünün tarihi gelişimi ve dönüşümü açısından önemli pek çok taktik ve teknolojik yeniliğin habercisi olmuştur. Bunların en önemlileri arasında, helikopterlerin savaştaki ilk büyük çaplı kullanımı ve taktik nakliye görevine getirdikleri büyük esneklik ve yetenek artış1 bulunmaktadır. Benzer şekilde, o güne kadar kullanılan ve hedefleri kinetik enerji ile yok eden silah ve mühimmata ilaveten, elektronik karıştırma ve aldatma teçhizatı ile tekniklerinin Vietnam Savaşı'yla birlikte havadaki mücadelenin vazgeçilmez unsurlarına dönüştüğünün altı çizilmelidir. Vietnam Savaşı vesilesiyle hava gücünün kullanımında yaşanan ve uzun vadede çok derin etkiler yaratan bir diğer dönüşüm, güdümlü füzelerin ve mühimmatın hava harekâtlarında boy göstermesidir. Bu kapsamda, Vietnam Savaşı'nda sahaya sürülen satıhtan-havaya uçaksavar füzeleri, o güne kadar stratejik saldırılarda kullanılan ağır bombardıman uçaklarını korunmasız kılarak, ibreyi daha küçük, kıvrak ve kendini koruyabilen av-bombardıman uçakları lehine çevirmiştir. Uçaklarca ateşlenen hava-hava füzelerin Vietnam Savaşı'nda sahne almasıyla, uçaklar arasındaki üstünlük mücadelesinin kuralları da yeniden tanımlamıştır. Orta vadede hava gücünün etkinliği üzerinde belki de en derin etkiyi yaratan gelişme ise,

\footnotetext{
${ }^{39}$ Benjamin S. Lambeth, The Transformation of American Air Power, Cornell UP, Ithaca, 2000, p. 54, 297.
} 
karadaki ve denizdeki hedeflere uzak mesafelerden nokta vuruşu yapılmasını imkân dâhiline sokan "hassas güdümlü mühimmat"1n Vietnam Savaşı'nın son evrelerinde sahadaki yerini almış olmasıdır. ${ }^{40}$ Tüm bu gelişmeler perspektifinde ele alındı̆̆ında, Vietnam Savaşı her ne kadar ABD'nin yenilgisiyle sonuçlanmış olsa da, yeni teknolojilerin, teçhizatın ve taktiklerin geliştirilerek tecrübe edilmesi için benzersiz fırsatlar sunmuş, bu sayede takip eden kırk yıl boyunca $\mathrm{ABD}$ hava gücüne rakipleri karşısında büyük üstünlük sağlayacak "askerî alanda devrim” olgusunun itici gücünü teşkil etmiştir. ${ }^{41}$ Bununla beraber, Vietnam Savaşı'nın tetiklediği teknolojik sıçramaların savaş alanlarındaki somut sonuçlarının görülebilmesi için 1991'deki Körfez Savaşı'nın beklenmesi gerekecektir.

Soğuk Savaş'ın sonlarına yaklaşılırken, İngiltere ile Arjantin arasında Falkland (Malvinas) Adaları yüzünden patlak veren kısa fakat şiddetli savaş, karada üslenmiş Arjantin uçaklarıyla binlerce kilometre öteden bölgeye intikal İngiliz deniz görev kuvveti arasındaki mücadeleye sahne olmuştur. Falkland Savaşı'nda yaşananlar, İkinci Dünya Savaşı'nda çıarılan önemli derslerden birisini tekrar hatırlatarak, denizdeki gemilerin kendi hava gücü unsurlarınca korunmadıkları takdirde uçaklar karşısında son derece kırılgan olabileceklerini teyit etmiştir. ${ }^{42}$ İngiliz uçak gemilerinden kalkan az sayıdaki savaş uçağının hem deniz görev kuvvetini, hem de adalara çıkarma yapan İngiliz kuvvetlerini Arjantin hava taarruzlarından koruyarak ibreyi yavaş yavaş İngiltere lehine çevirmesi, İkinci Dünya Savaşı'nda Pasifik cephesinde şekillenen ve deniz savaşlarında uçaklar karşısındaki en etkin savunmanın yine uçaklarca sağlanabileceği tecrübesinin bir tekrarı olarak görülebilir.

Soğuk Savaş'ın son büyük çaplı askerî harekâtı olan Afganistan'ın Sovyetler Birliği'nce işgali de hava gücünün yoğun ama somut sonuçlar üretmeyen kullanımına sahne olmuştur. Sovyetlerin Afganistan'daki iç savaşa

\footnotetext{
${ }^{40}$ Mike Benitez ve Mike Pietrucha, "Political Airpower, Part II: The Seductive Allure of Precision Weapons", War on the Rocks, https://warontherocks.com/2016/11/politicalairpower-part-ii-the-seductive-allure-of-precision-weapons/ (Erişim Tarihi: 09.06.2020).

${ }^{41}$ Wayne Thompson, "Operations Over Vietnam", John A. Olsen (ed.), A history of air warfare, Potomac Books, Vaşington, 2010, 107-126, p. 107.

${ }^{42}$ Dov S. Zakheim, "The South Atlantic: Evaluating the Lessons", James Brown ve William P. Snyder (ed.), The Regionalization of Warfare, Transaction Books, New Jersey, 1985, 37-54, p. 43-52.
} 
müdahalesi, devasa boyutlarda hava köprüsü kurularak Sovyet birliklerinin ülkeye havadan intikaliyle başlamıştır. Devamında yer taarruz uçakları ve helikopterler, Afganistan'ın dağlık coğrafyasında yürütülen kara harekâtına destek vermiştir. Ancak, ABD'nin bundan sadece birkaç yıl önce Güneydoğu Asya ormanlarındaki acı tecrübelerini yaşama sırası bu kez Sovyetlerdedir. Zira kırsal kesime dağılarak gerilla harbi taktiklerine başvuran hasımlar karşısında hava gücünün etkinliği azaltmış; ABD'nin Afgan direnişçilere temin ettiği omuzdan atılan uçaksavar füzeleri Sovyet uçak ve helikopterlerinin hareket serbestisini iyice kısıtlamıștır. Diğer taraftan, Afganistan gibi son derece zorlu yüzey şekillerinin hâkim olduğu bir coğrafyada havadan ikmal ve takviye yapılabilmesinin karadaki operasyonların devamı açısından taşıdığı kritik önem görülmüş ve Kızıl Ordu'nun yüz binden fazla mensubu Afganistan'daki varlıklarını büyük oranda hava gücü sayesinde sürdürebilmişlerdir. ${ }^{43}$

Soğuk Savaş yıllarında hava gücü sadece süper güçlerce değil, muhtelif bölgesel güçlerce bölgesel çatışmalarda da kullanılmıştır. 1965'te Hindistan ile Pakistan arasındaki savaş, bir yandan hava gücünün kullanımı açısından hiçbir yenilik veya yaratıcılık içermezken, diğer yandan hava gücünü oluşturan bileşenlerin temininde yurt dışına bağımlı devletlerin savaşmaya karar verirken ne kadar dikkatli olmaları gerektiğini göstermiştir. Zira Hindistan ile Pakistan arasındaki hava mücadelesi, iki tarafa da uygulanana silah ambargosu nedeniyle kısa sürede durma noktasına gelmiştir. ${ }^{44} 1974$ 'te Türkiye'nin Kıbrıs adasına yönelik harekâtındaysa, her ne kadar hava gücüne sahip olmayan Rum kuvvetleri karşısında Türk Hava Kuvvetleri'nce hava hâkimiyeti süratle kurulmuş, başarılı hava indirme harekâtları icra edilmiş ve karadaki çatışmalara etkili yakın hava desteği sağlanmış olsa da, aynı zamanda yerden açılan ateş sonucu uçakların uğradığı kayıplar önemli seviyelere tırmanmıştır. ${ }^{45}$ İlaveten, deniz kuvvetlerine havadan verilen ateş desteğinde komuta-kontrol, eşgüdüm ve doğru teşhisin taşıdığı hayati önem bir Türk destroyerinin yanlışlıkla

\footnotetext{
${ }^{43}$ Brown, Air Power, p. 16-17.

${ }^{44}$ Higham, Concise History, p. 225-226.

${ }^{45}$ Erol Mütercimler, Kıbrıs Harekatının Bilinmeyen Yönleri, Yaprak Yayınevi, İstanbul, 1990, s. 296.
} 
batırılmasıyla bir kez daha ispatlanmıştır. ${ }^{46}$ Diğer taraftan, 1978'teki ÇinVietnam ve 1980-1987'deki İran-Irak savaşlarında hava gücünün oynadığ tali rol, net ve ulaş1labilir siyasî hedeflerden yoksun askerî kuvvet kullanımına sahne olan çatışmalarda yaratıcılıktan uzak şekilde kullanılan hava gücünün fazlaca bir etki yaratamadığına işaret etmektedir. ${ }^{47}$

Soğuk Savaş yıllarında hava gücünün kullanımı açısından yenilik veya yaratıcılık içermeyen diğer pek çok bölgesel çatışmayla kıyaslandığında, 1967, 1973 ve 1982 yıllarındaki Arap-İsrail savaşları önemli yenilikler ve dersler barındıran istisnalar olarak öne çıkmaktadır. 1967 Altı Gün Savaşı'nda kendinden sayıca üstün Arap hasımlarını henüz havalanmaya bile fırsat bulamadan karşı-hava harekâtıyla saf dışı bırakan İsrail hava kuvvetleri, devamında İsrail ordusunca karada başarıyla icra edilen yıldırım savaşına etkin destek sağlayarak çarpıcı bir zafer elde edilmesinde birincil rolü oynamıştır. Sürpriz etkisinin yanı sıra nitelikli ve iyi eğitilmiş personel, keşif-istihbarat kabiliyeti ve kendi kuvvetli yönleriyle rakibinin zayıf noktalarının doğru şekilde değerlendirilmesi bir araya gelerek hava gücünün İkinci Dünya Savaşı'ndan o güne kadarki en çarpıcı sonuçları almasını sağlamıştır. ${ }^{48}$ Fakat 1967 'de elde ettiği başarının parlaklığından gözleri kamaşan İsrail, o sıralar yaşanmakta olan teknolojik dönüşümü doğru şekilde algılamakta gecikmiş ve 1973'te Arap ordularının sürpriz saldırısına uğradığında, büyük bir kendine güvenle giriştiği savaşta hezimete uğramaktan zorlukla kurtulabilmiştir. Ekim Savaşı ve Yom Kipur Savaşı isimleriyle bilinen bu çatışmada, Arap ordularını kolaylıkla geri püskürtecekleri beklentisiyle sahaya sürülen İsrail uçakları, Suriye ve Mısır'ın kısa süre önce Sovyetler Birliği'nden temin ettiği ve aynıları Vietnam'da ABD uçaklarına zor anlar yaşatmış olan uçaksavar füzeleri karşısında o denli ağır kayıplara uğramıştır ki, uçak envanterinin sadece günler içerisinde eriyerek elden çıkacağından kaygı duyan İsrail Hava Kuvvetleri, karadaki birliklerinin acil destek çağrılarına rağmen uçuşlarını durdurmak zorunda kalmıştır. Takip eden haftalarda Arap ordularının uçaksavar sistemlerince sağlanan hava savunma şemsiyesinin dişına çıkmakta isteksiz davranmasıyla

\footnotetext{
${ }^{46}$ Edward J. Erickson and Mesut Uyar, Phase Line Attila, Marine Corps UP, Quantico, 2020, p. 135-139.

${ }^{47}$ Brown, Air Power, p. 120-125.

${ }^{48}$ Jeoffry Kemp, Arms and Security: The Egypt-Israel Case, IISS, Londra, 1968, p. 2-11.
} 
Hava Gücünün Tarihi Gelişimi: Nitelikler, Bileşenler, Görevler ve Etkinlik Açısından Bir Değerlendirme

karadaki inisiyatifi tekrar ele geçiren İsrail ordusu, hava gücü desteğinden yoksun olarak gerçekleştirdiği karşı saldırılarla Mısır ve Suriye'yi ateşkes imzalamaya zorlayabilmiştir. ${ }^{49}$

Ekim Savaşı'ndan dokuz yıl sonra 1982'de Bekaa Vadisi üzerinde Suriye ile yaşadığı hava mücadelesinde İsrail Hava Kuvvetleri, 1973'teki başarısızlığından gereken dersleri çıkartarak rakibinin satıhtan-havaya füzeler etrafında şekillenmiş entegre hava savunma mimarisini alt edebilecek bir dizi yeni taktik ve teknolojiyi hayata geçirmiş ve sonuçta havacılık tarihinde fazla benzeri bulunmayan bir başarıya imza atmıştır. Gelişmiş elektronik karıştırma ve aldatma teknikleri, İHA'lar, sahte hava hedefleri, hassas güdümlü mühimmat, radar dalgalarının odağına yönelen füzeler gibi bir dizi teknolojik yeniliğin yaratıcı taktiklerle harmanlanarak sahaya sürülmesiyle, neredeyse saatler içerisinde 82 Suriye savaş uçağı düşürülüp düzinelerce hava savunma mevziisi imha edilirken, İsrail'in kayıları sadece tek bir uçakla sınırlı kalmıştır. ${ }^{50}$

\subsection{Soğuk Savas Sonrası Dönem}

Doğu ve Batı blokları arasında neredeyse yarım asırdır devam eden Soğuk Savaş, 1980’lerin sonlarından önce Varşova Paktı, ardından Sovyetler Birliği'nin dağılmasıyla ani ve beklenmeyen şekilde sonlanmıștır. Tam da bu dönemde Irak'in Kuveyt'i işgal etmesi ve akabinde Irak'1 Kuveyt'ten çıkartmak için $\mathrm{ABD}$ önderliğinde girişilen Körfez Savaşı, hava gücünün modern harbin neredeyse her boyutu üzerindeki etkisini şüpheye yer bırakmayacak şekilde gözler önüne sermiştir. 1991 Körfez Savaşı'nda hava gücünün etkin kullanımı için daha önceki savaşlardan elde edilen tecrübeler neredeyse eksiksiz uygulanarak hava harekâtı takip eden dört safhada gerçekleştirilmiştir: i) Irak'ın hava gücü unsurlarına ve destekleyici altyapısına yönelik saldırılar sayesinde hava hâkimiyetinin süratle ele geçirilmesi; ii) Kuveyt harekât sahasındaki Irak hava savunma unsurlarının yok edilmesi; iii) Kuveyt'te konuşlanmış Irak kara birliklerinin havadan sürekli ve yoğun şekilde bombalanması; iv) kara taarruzu başladığında

\footnotetext{
${ }^{49}$ Frank Aker, October 1973: The Arab-Israeli War, Archon Books, Hamden, 1985, p. 43.

${ }^{50}$ Shmuel L. Gordon, “Air Superiority in Israeli-Arab Wars”, John A. Olsen (ed.), A history of air warfare, Potomac Books, Vaşington, 2010, 137-166, p. 150-152; John A. Warden III, The Air Campaign - Planning for Combat, National Defense UP, 1988, p. 57-58.
} 
koalisyon güçlerine yakın hava desteği sağlanması. Yaklaşık beş haftalık zaman dilimine yayılan ilk üç safhada Kuveyt'teki Irak birlikleri havadan tecrit edilip kötü şekilde hırpaladıklarından ve savaşma azimlerini kaybettiklerinden, dördüncü safha yani kara harekâtı safhası fazla bir dirençle karşılaşmadan sadece beş gün içerisinde tamamlanarak harekâtın askerî ve siyasî amaçlarına ulaşılmıştır. ${ }^{51}$

Körfez Savaşı'ndaki uygulanış şekli bir yandan hava gücünün modern savaşlardaki etkin kullanımına yönelik bir şablon ortaya koyarken, diğer yandan da elde ettiği hızlı ve çarpıcı sonuçlar geniş kitlelerin hava gücü algısını dönüştürmüştür. ${ }^{52} \mathrm{Bu}$ manada, artık savaşların daha iyi eğitimli, daha üstün donanıma ve daha ileri teknolojiye sahip hava kuvvetlerince kolaylıkla, süratle ve fazla can kaybı yaşanmadan kazanılacağı beklentisi oluşmuştur. Esasen kitlelerin sadece hava gücü değil, savaşa yönelik algısı da değişmiş; radara görünmeme, hassas güdümlü mühimmat, seyir füzeleri, ağ ve uzay destekli haberleşme, uydudan tespit-takip gibi egzotik teknolojileri ve imkânları hava gücü bünyesine dâhil edebilen devletlerin gelecekteki tüm savaşların kazananı olacağı algısı ve beklentisi ortaya çıkmıştır.

1991'de yaşananlara daha temkinli yaklaşan diğer bazı araştırmacılarsa, Körfez Savaşı'nın istisnai şartlarına işaret ederek, elde edilen çarpıcı başarının her zaman tekrar edilemeyeceği, dolayısıyla geleceğe yönelik önermeler yaparken dikkatli davranılması gerektiği uyarısında bulunmuşlardır. Temkinli yaklaşımı benimseyenlerin işaret ettiği Körfez Savaşı'na özgü şartlardan belki de en önemlisi, hava gücünün gerektirdiği fizikî, insan gücü ve teknolojik imkânlara fazlasıyla sahip Dünya'nın tek süper gücünün, Soğuk Savaş'ın bitmiş olmasından istifade ederek elindeki hava gücünün neredeyse tamamını Irak gibi hava gücü sicili zaten parlak olmayan bölgesel bir güç üzerine yoğunlaştırabilmiş olmasının ortaya koyduğu istisnai durumdur. ${ }^{53}$ Gerçekten de, ABD önderliğindeki koalisyon uçaklar, hassas güdümlü mühimmat, istihbarat, insan gücü ve destekleyici altyapı

\footnotetext{
${ }^{51}$ Thomas A. Keaney ve Eliot A. Cohen, Revolution in Warfare? Air Power in the Persian Gulf, Naval Institute Press, Annapolis, 1995, p. 55-60.

52 Öneğin bkz. John F. Jones, Jr., "Giulio Douhet Vindicated: Desert Strom 1991", Naval War College Review, 1992, Cilt 45, Say1 1, 97-101, p. 97-100.

${ }_{53}$ Operation Desert Storm Air War. Letter Report by General Accounting Office, GOA, Washington, 1996, p. 232-234.
} 
gibi hemen her boyutta Irak karşısında hem nitelik, hem nicelik açısından ezici üstünlüğe sahip olmuştur. İlaveten, Irak'a yönelik saldırının başlama zamanı, yeri ve şeklini belirleme ayrıcalığına sahip olunması; saldırı öncesinde beş ayı aşkın yoğun bir hazırlık ve planlama süresinin kullanılabilmesi; Kuveyt ile Irak'ın güneyinin, uçakların kullanımı için en uygun arazi yapısı olan çöller ve geniş düzlüklerden oluşması hava gücünün lehine çalışan diğer etkenler arasında sayılmaktadır. ${ }^{54}$ Temkinli yaklaşımı benimseyenler özetle, taraflar arasındaki büyük dengesizlik başta olmak üzere Körfez Savaşı'nın tabi olduğu istisnai şartlara işaretle, hava gücünün modern savaşların seyrini ve sonucunu tek başına belirleyebilecek en önemli askerî kuvvet unsuruna dönüştüğü çıkarımının yapılamayacağını savunmaktadir.

$\mathrm{Bu}$ arada, Körfez Savaşı'ndaki göz kamaştırıcı başarının ardında aslında hava gücünden ziyade, bilgi teknolojilerinde yaşanan devrimsel nitelikteki gelişmelerin aranması gerektiğini savunan üçüncü bir görüşün varlığından da bahsedilmelidir. Bu bakış açısına göre, eskiye kıyasla çok büyük hacimlerde verinin toplanması, işlenmesi ve aralarında hava gücü unsurlarının da bulunduğu kullanıcılara anında ulaştırılabilmesi, hem savaşların süresini kısaltmış, hem de askerî güç kullanımının etki sahasını misliyle artırmıştır. Bazılarınca "Bilgi Savaşı" olarak adlandırılan bu yeni savaş türünün artık Yıldırım Savaşı'nın yerini aldığı, dolayısıyla Körfez Savaşı'nda kazanılan başarının sadece hava gücüne mal edilemeyeceği öne sürülmüştür. ${ }^{55}$

Devam eden tartışmalar bir yana, hava gücünün Körfez Savaşı'nda elde ettiği etkileyici başarı bundan birkaç yıl sonra Yugoslavya'da patlak veren iç savaşın kontrol altına alınması için hava gücünün tercih edilmesinde etkili olmuştur. Bosna-Hersek'te kıyım yapmakta olan Sırp askerî ve yarıaskerî kuvvetlerine karşı gerçekleştirilen müdahalede, sekiz NATO ülkesine ait savaş uçaklarınca gerçekleştirilen hava saldırıları sayesinde Sırp askerî hareketliliği durdurulmuş, akabinde bir barış anlaşmasının imzalanması

54 Eliot A. Cohen, "The Air War in the Persian Gulf", Armed Forces Fournal International, Haziran 1993, Cilt 10, Say1 13, 10-14, p.10-11.

${ }_{55}$ Bill Sweetman, "Catching up with doctrine", Fane's Defence Weekly, 29 June 1991, p. 1174-1175. 
için gerekli ortam yaratılmıştır. ${ }^{56} 1999$ 'da bu kez Kosova'daki çatışmalar nedeniyle yine Sırp hedeflerine karşı yapılan NATO hava taarruzları da kıyaslanabilir sonuçlar doğurmuştur. ${ }^{57}$ Hâlâ büyük oranda güdümsüz bombaların kullanıldığı Körfez Savaşı'na kıyasla, eski Yugoslavya semalarındaki hava harekâtlarının getirdiği önemli yenilik, NATO uçaklarınca neredeyse $\% 100$ oranında hassas güdümlü mühimmata başvurulmuş olmasıdır. \%100 oranında hassas güdümlü mühimmatın kullanıldığı "cerrahi" isabet hassasiyetine sahip hava saldırıları önce ABD, yıllar içerisinde Batı Avrupa ülkeleri ile İsrail ve Türkiye'nin gerçekleştirdiği hava harekâtlarının olmazsa olmazına dönüşmüştür. Daha kısıtlı mali ve teknolojik imkânlara sahip bölgesel güçlerin yanı sıra, özellikle Rusya'nın hava harekâtlarında hâlâ daha düşük maliyetli güdümsüz mühimmat kullanmayı tercih ettiği, dolayısıyla sivil can ve mal kayıplarını göze aldığının altı çizilmelidir. ${ }^{58}$

2001'de Afganistan'ın ve 2003'te Irak'ın işgali sırasında ABD ile müttefiklerinin hava gücü kullanımının gerek elde edilen sonuçlar, gerekse kullanılan taktikler ve teknolojiler açısından fazlaca bir yenilik içermediği vurgulanmalıdır. Bu bakımdan belki daha önemlisi, hava gücünün desteğiyle elde edilen süratli başarının, saldırının sona ermesini müteakip karadaki kontrolün sağlanmasını ve hava harekâtının siyasî hedeflerine ulaşılmasını garanti etmediğinin, ABD'nin Afganistan ve Irak'ın işgali sonrasında yaşadığı sıkıntılı ve yüksek maliyetli süreçler sayesinde gözler önüne serilmiş olmasıdır. ${ }^{59}$ 2011'de NATO hava kuvvetlerince Libya'daki iç savaşı durdurmak iddiasıyla başlatılan havadan müdahalenin de, Kaddafi rejiminin devrilmesinden sonra ülkenin çok daha ciddi belirsizlik ve çatışma ortamına yuvarlanmış olması itibarıyla aynı çerçevede

\footnotetext{
${ }^{56}$ Tim Ripley, “Air Power Vindicated”, Flight International, https://www.flightglobal.com/ air-power-vindicated/13790.article (Erişim Tarihi: 1 Haziran 2020).

57 Daniel L. Byman ve Matthew C. Waxman, "Kosovo and the Great Air Power Debate", International Security, 2000, Cilt 24, Sayı 4, 5-38, p. 5-6.

${ }^{58}$ Tom Cooper, "Here's the Key to Understand the Russian Air Force's Actions in Syria”, War Is Boring, https://warisboring.com/heres-the-key-to-understanding-therussian-air-forces-actions-in-syria/ (Erişim Tarihi: 09.06.2020).

${ }^{59}$ Mike Pietrrucha and Jeremy Renken, "Air Power May Not Win Wars, But It Sure Doesn't Lose Them”, War on the Rocks, https://warontherocks.com/2015/08/airpowermay-not-win-wars-but-it-sure-doesnt-lose-them/ (Erişim Tarihi: 09.06.2020).
} 
Hava Gücünün Tarihi Gelişimi: Nitelikler, Bileşenler, Görevler ve Etkinlik Açısından Bir Değerlendirme

değerlendirilmesi mümkündür. ${ }^{60}$ Suudi Arabistan ile müttefiklerinin son dönemde Yemen'deki iç savaşa karadan ziyade hava gücüne ağırlık vererek gerçekleştirdikleri müdahale ise, yetersiz eğitim ile personel kalitesi, teknoloji üzerindeki sınırlı hâkimiyet gibi etkenlerce örselendiğinde, havadaki mutlak üstünlügün karada başarı sağlamaya yetmediğine örnek olarak gösterilebilir. ${ }^{61}$ Aslında Rusya'nın 2015'ten itibaren Suriye'deki iç savaşa havadan gerçekleştirdiği müdahale de, her ne kadar dengeyi rejim güçleri lehine çevirerek Moskova'ya önemli siyasî avantajlar sağlamış olsa da, aradan geçen beş yıla rağmen Suriye'deki iç savaşın hâlâ devam ediyor olması göz önüne alındığında, hava gücünün özellikle iç savaş ve gayrinizami harp senaryolarında sonucu tek başına belirleyememesinin güncel bir örneğini teşkil etmektedir.

2001 yılındaki 11 Eylül saldırılarına cevaben önce ABD, devamında İngiltere, Fransa ve İtalya gibi yakın müttefiklerinin terörle mücadele nitelemesi altında Afganistan'dan Orta Doğu'ya ve Afrika'ya uzanan geniş bir coğrafyada yürüttüğü operasyonlar, istifade ettikleri gelişmiş teknolojiler ve bu kapsamda özellikle İHA'ların yaygınlaşması itibarıyla değinilmeyi hak etmektedir. Havada kalış zamanı görece sınırlı insanlı uçaklara kıyasla muhtemel hedef bölgeleri üzerinde çok daha uzun sürelerle gözetleme görevi icra edebilen İHA'lar, 1990'lardan itibaren veri derlemeişleme-paylaşım alanlarında yaşanan süratli teknolojik gelişmeler sayesinde, geniş arazi dilimlerine yayılmış ve sivillerle iç içe geçmiş teröristlerin tespiti ve ısrarlı takibinde ağırlıklı rolü üstlenmiştir. Hava gücünün asli keşif ve gözetleme görevinin gelişen teknolojiye koşut olarak "ISR" (intelligence-surveillance-reconaissance) adıyla günümüz şartlarına uyarlanmasından ibaret olan bu kullanım tarz1, 2001'den itibaren İHA'ların hassas güdümlü mühimmat ateşleme kabiliyetini kazanmasıyla, hava gücünün geleneksel isyan bastırma görevinin bir türevi olarak sınıflandırılabilecek terörle mücadele operasyonlarını içine alacak şekilde

\footnotetext{
${ }^{60}$ Stephen Biddle, "The Libya dilemma: The limits of air power", The Washington Post, https://www.washingtonpost.com/opinions/the-libya-dilemma-the-limits-of-air-power/ 2011/03/25/AFfTVUYB_story.html (Erişim Tarihi: 09.06.2020).

${ }^{61}$ Stasa Salacanin, "What is behind Saudi military failures?", Middle East Monitor, https://www.middleeastmonitor.com/20191010-what-is-behind-saudis-military-failures/

(Erişim Tarihi: 9 Nisan 2020).
} 
genişlemiştir. 2015-2018 döneminde Deaş terör örgütüne karşı Suriye ve Irak'ta yürütülen hava harekâtları bağlamında, İHA'ların kendilerinin ve hedefe yönlendirdikleri saldırı uçaklarının hassas güdümlü mühimmat kullanarak elde ettiği başarılı sonuçlar açısından ele alındığında, gerilla harbi taktiklerine başvuran hasımlar karşısında ibrenin sonunda hava gücü lehine dönmeye başladığı yorumu yapılabilir. Buna karşılık, Afganistan, Somali ve Sahel ülkeleri gibi coğrafyalarda kırsala dağılmış terörist grupların faaliyetlerini sona erdirmekte İHA'ların ve onların hedeflere yönlendirdiği hava gücü unsurlarının arzu edilen sonuçları bir türlü üretemediği, karadan müdahale gerçekleşmediği sürece terörist grupların kökünün kazınamadığına tanıklık edilmektedir. İlaveten, Musul ve Rakka şehirlerinin Deaş'dan geri alınması sırasında yaşanan yıkımın ve sivil can kayıplarının boyutları, son dönemde kaydedilen tüm teknolojik gelişmelere rağmen, teknolojik gelişimin hava gücüne sağladığı cerrahi hassasiyetle isabet imkânının kentsel alanlarda büyük oranda ortadan kalktığı görülmektedir. ${ }^{62}$

Konuyu İHA'ların yaygınlık kazanmasının hava gücünün dönüşümü üzerindeki etkileri açısından ele almak gerekirse, insanlı uçaklarla kıyasla daha çabuk ve ucuza geliştirilip tedarik edilebilen, düşmesi halindeyse can kaybı söz konusu olmayacağından siyasî otorite tarafından kolaylıkla gözden çıkarılabilen İHA'ların, önümüzdeki yıllarda yeni kullanım sahaları bulması ve yaygınlaşmaya devam etmesi beklenmelidir. Nitekim Türkiye'nin 2020'de Suriye ve Libya'da sergilediği sistematik İHA kullanımı, hava gücünün geleneksel görevleri arasında yer alan tecrit ve yakın hava desteğinin artık İHA'larca üstlenilebildiğini ispatlamıştır. ${ }^{63}$ Buna karşılık İHA kullanımına konu olan coğrafyanın ve savaşan tarafların kendine has askerî ve siyasî şartları bir kenara not edilmeli; İHA'ların Kuzeybatı Suriye ile Libya semalarında aldığı başarılı sonuçların diğer çatışmalara, özellikle de hava

${ }^{62}$ Elias Groll and Robbie Gramer, "How the U.S. Miscounted the Dead in Syria", Foreign Policy, https://foreignpolicy.com/2019/04/25/how-the-u-s-miscounted-the-deadin-syria-raqqa-civilian-casualties-middle-east-isis-fight-islamic-state/ (Erişim Tarihi: 09.06.2020); Michael Jackson vd., "Modern Siege Warfare”, Foreign Affairs Magazine, https:/www.foreignaffairs.com/articles/syria/2016-12-07/modern-siege-warfare (Erişim Tarihi: 09.06.2020).

${ }^{63}$ Dylan Nicholson, "Foreign drones turning the tide in Libya", Defence Connect, https://www.defenceconnect.com.au/strike-air-combat/6218-foreign-drones-turningthe-tide-in-libya (Erişim Tarihi: 09.06.2020). 
Hava Gücünün Tarihi Gelişimi: Nitelikler, Bileşenler, Görevler ve Etkinlik Açısından Bir Değerlendirme

gücü birbirine daha denk aktörler arasındaki konvansiyonel savaşlara uyarlanmasında temkinli davranılmalıdır. Ayrıca son dönemde kullanımlarının süratle artıyor olması, İHA'ların artık insanlı uçakların yerini almakta olduğu şeklinde yorumlanmamalıdır. Daha ziyade, insanlı uçakların hava harekâtlarının merkezinde yer aldığ 1 , ama giderek artan yoğunluk ve şekillerde insansız uçaklarla iş birliği yaptıkları ve harekâtlara onlarla birlikte katıldıkları bir gelecek öngörüsü daha gerçekçi olacaktır. ${ }^{64}$

Son yıllarda giderek süratlenen teknolojik gelişmelerin hava gücü üzerindeki etkisi salt İHA'larla sınırlı kalmamaktadır. Otonom sistemlerle onları destekleyen "yapay zekâ" ve "sürü" teknolojileri gibi alanlarda kaydedilen sıçramalar, akıllı mühimmatın ve füzelerin giderek daha uzak mesafelerdeki hedefleri kendi başlarına ve savunma önlemlerini atlatarak vurmasını mümkün kılmakta, dolayısıyla ilk günden bu yana hava gücünün ana bileşeni sayılan muharip uçakları, başkalarınca tespit edilmiş hedeflere akıllı mühimmat firlatan birer silah taşıyıcı platforma dönüştürmektedir. ${ }^{65}$ Hava gücünü oluşturan tüm unsurların sadece birbirleriyle değil, karada, denizde ve uzaydaki dost kuvvetlerle yakın temas, iş birliği ve veri alışverişi içinde bulunmalarına dayalı "ağ merkezli harp" olgusuysa, daha uzaktaki hedeflerin, daha az sayıda platformla, daha kısa sürede ve daha isabetli şekilde vurulmasını sağlayarak, 1991 Körfez Savaşı'nda hava gücü etrafında şekillenen daha hızlı ve daha etkili askerî güç kullanımı olgusunu kuvvetlendirmektedir. ${ }^{66}$ Ancak bu varsayımların, terörle mücadele veya siber savaş gibi olasılıkları içeren asimetrik harp senaryolarında ne dereceye kadar geçerli olacağının veya birbirine teknolojik açıdan yakın güçler arasındaki karşılaşmalarda nelerin yaşanabileceğinin dikkatle ve her bir vaka için ayrı ayrı irdelenmesi yerinde olacaktır.

Diğer taraftan teknolojik gelişmeler her zaman hava gücünün lehine çalışmamakta, bazı alanlardaki gelişmeler hava gücünün bekasına

${ }^{64}$ Jacquelyn Schneider ve Julia Macdonald, "Why Troops Don't Trust Drones", Foreign Affairs Magazine, https://www.foreignaffairs.com/articles/united-states/2017-1220/why-troops-dont-trust-drones (Erissim Tarihi: 10.06.2020).

${ }^{65}$ Valeria Insinna, “As Force Shrinks, USAF Eyes Ways to Amass Forepower”, Defense News, 11 Temmuz 2016, p. 11.

${ }^{66}$ Pat Host, "US Air Force plans big investments towards digital architecture and space capabilities", Fane's Defence Weekly, 6 Kasım 2019, p. 16. 
ve etkinliğine yönelik tehditlere dönüşebilmektedir. Örneğin son dönemde, Rusya ve Çin gibi güçlerin konuşlandırdığı uzun menzilli hava savunma sistemlerine dayalı "erişimi engelleme / bölgeye sokmama" ( $A 2 / A D$ - anti-access/area denial) kabiliyetine işaretle, hava gücünün kendinden beklenen sonuçları almasının artık şüpheli hale geldiği iddialarına özellikle Batı ülkelerinde sıklıkla rastlanmaktadır. Fakat 2017'den bu yana İsrail ve ABD'nin seyir füzesi ve hava taarruzları kapsamında Suriye'de, ardından 2019'da petrol tesislerine yönelik seyir füzesi ve intihar IHHA'sı saldırıları vesilesiyle Suudi Arabistan'da yaşananlar, A2/AD yetenekleri etrafında şekillenen bu kaygıların abartılı olabileceğine işaret etmektedir. Zira son dönemde sahada yaşananlar, uzun menzilli güdümlü mühimmat, seyir füzeleri, insansız uçaklar, elektronik harp ve diğer aldatma tekniklerini içeren sistematik saldırılar karşısında hava savunma sistemlerinin hantal ve kırılgan duruma düşebildiğini göstermektedir. ${ }^{67}$ Başka bir ifadeyle, havadaki mücadelede saldırı ile savunma arasındaki dengenin savunma lehine bozulduğu, dolayısıyla modern savaşlarda hava gücünün saldırı unsurlarının bekasının ve etkinliğinin azaldığ 1 iddialarını destekleyecek kanıtlara sahip değiliz. Tersine, askerî havacılığın tarihi gelişimindeki diğer pek çok örneğe bakarak, avantajın genelde hava gücünün inisiyatif ve esneklik özelliklerini kullanabilen, yani taarruz eden tarafa geçtiğini söylemek mümkündür.

\section{Sonuç ve Gözlemler}

Hava gücünün ortaya çıkmasından günümüze kadar geçen 100 yılı aşkın zaman zarfında yaşananlar, hava gücünün kullanımı ve modern savaşlardaki yeri hakkında bazı çıkarımlarda bulunulmasına izin vermektedir.

Öncelikle, hava gücünün başlangıçtaki kara ve deniz gücüne tabi ikincil askerî güç konumundan kurtularak, yıllar içerisinde süratle olgunlaştı̆̆ına ve modern savaşların vazgeçilmez, birincil askerî güç unsurları arasına katıldığına şüphe yoktur. Özellikle 1991 Körfez Savaşı'ndan sonra savaşların niteliğinin ve sonucunun satıhta belirleneceği, hava gücününse

${ }^{67}$ Robert Dalsjö vd., Bursting the Bubble: Russian A2/AD in the Baltic Region, FOI Swedish Defence Research Agency, Stockholm, 2019, p. 10-11. 
denizlerde ve özellikle de karadaki çatışmalara yapabildiği katkı ölçüsünde önem taşıdığını savunan geleneksel bakış açısı geçerliliğini kaybetmiştir. Ancak bu saptama, hava gücünün savaşları tek başına kazanabileceği, dolayısıyla kara ve deniz kuvvetleri karşısında baskın konuma geçtiği şeklinde yorumlanmamalıdır. Zira hava gücü sayesinde elde edilen üstünlügün ve yaratılan fırsatların kullanılabilmesi, taktik, stratejik ve/veya siyasî sonuçlara çevrilebilmesi için satıhta konuşlanmış kuvvetlere hâlâ ihtiyaç duyulmaktadır. İlaveten, hava gücünü oluşturan hava araçlarının düşmanın kinetik ve elektronik saldırıları karşısındaki kırılganlığı sürmekte, hava araçları hâlâ hava üsleri gibi simetrik ve asimetrik tehditlere açık kapsamlı altyapıya ihtiyaç göstermektedir. Her hava harekâtının kendine has coğrafî şartları, hatta iklim ve hava koşulları da kısıtlayıcı olabilmektedir. Özellikle son dönemde hava gücünün etkinliğini dramatik şekilde artıran teknolojik gelişmelerse, hasımlarca hava gücü unsurlarını yok etmeye veya faaliyetlerini kesintiye uğratmaya yönelik olarak da kullanılabilecektir. Hava gücü ile onu etkisiz kılmaya yönelik tedbirler arasındaki mücadele devam edeceğinden, hava gücünün diğer kuvvet kategorilerine kıyasla baskın, savaşların sonucunu tek başına belirleyebilecek, her şart ve ortamda kendinden beklenen sonuçları üretebilecek kapasiteye ulaştığı çıkarımı yapılamamaktadır.

Tarihi gelişim sürecine dayanarak yapılabilecek ikinci bir önerme, teknolojik gelişmelere koşut olarak hava gücünün bileşenlerinin görev icra ediş şekilleri, yetenekleri ve performanslarının süratle değişiyor olmasına karşın, hava gücünün ayırt edici niteliklerinin ve özellikle de icra ettiği görev kategorilerinin amaçları itibarıyla fazlaca değişikliğe uğramadığı, hatta büyük oranda aynı kaldığıdır. Kuşkusuz hava gücünün çeşitli görevleri icra ediliş şekli, kullanılan araçlar ve teknolojiler itibarıyla yıllar içerisinde büyük değişimlerden geçmiştir, geçmeye de devam edecektir. Ama yine de hava gücünün bazıları bundan yüz yıl önce şekillenen görevleri, elde etmeye çalıştıkları hedefler itibariyle günümüzde de geçerliliğini korumaktadır. Benzer şekilde, hava gücünün ayırt edici nitelikleri olarak bundan bir asır önce işaret edilen esneklik, çok yönlülük ve diğer askerî güç unsurlarıyla sinerji yaratma üstünlükleri günümüzde de geçerliliğini korumaktadır. Aynı durum, hava gücünün kullanımıyla bu kullanımdan hedeflenen siyasî amaçların birbiriyle tutarlı olması gerektiği önermesi için de geçerlidir. Zira bir devletin gerçekçi ve ulaşılabilir siyasî hedeflerden 
bağımsız olarak hava gücünün kullanımıyla elde edebileceği taktik başarılar geçici olmakta, ulusal çıkarlara hizmet etmeyebilmekte, hatta kaynak israfına yol açarak o devletin uluslararası sistemdeki göreceli gücünü azaltabilmektedir. Özellikle Körfez Savaşı'ndan sonra akademik olmayan yazım ve düşünce çevrelerinde, hatta bazı siyasî karar vericiler nezdinde kabul gören ve hava gücünün nihai siyasî hedeflerden bağımsız olarak her şartta ve firsatta sahaya sürülerek bir şekilde mucizevî sonuçlar ve çözümler yaratacağı beklentisi sahadaki gerçeklerle örtüşmediği gibi, uluslararası barış ve istikrar açısından tehlikeye işaret etmektedir.

Hava gücünün gelişim sürecindeki bazı somut örneklere dayanılarak yapılabilecek son bir saptama, nicelik ve/veya nitelik açılarından daha üstün uçaklar, mühimmat ve destekleyici altyapı unsurlarına sahip olunmasının hava gücünün potansiyelinden tam manasıyla yararlanılmasını garanti etmeyebildiğidir. Bu yönüyle, her çatışmanın kendine has kısıtlayıcı veya kolaylaştırıcı şartlarının ötesinde, hava gücü bakımından denk bir rakiple karşı karşıya olunup olunmadığı ve sahip olunan ekipman ile personelin nitelikleri de alınacak sonuç üzerinde etkili olmaktadır. $\mathrm{Bu}$ meyanda, hava gücünün uçaklar ve mühimmat gibi son derece yüksek maliyetli maddi bileşenleri kadar, bu bileşenleri kullanan personelin yüksek nitelikli ve eğitimli olması da belirleyici olmaktadır. İlaveten, hava gücünün kullanımında belli bir tecrübeye sahip olunması, ya da en azından diğerlerinin tecrübelerini inceleyip gerekli dersleri çıkaracak ve bu dersleri kendi şartlarına uyarlayabilecek esneklikte kurumsal ve entelektüel kapasiteye sahip olunması da önem taşımaktadır. Ve en nihayet hava gücünün barındırdığı ileri teknolojileri salt kullanmanın ötesinde, bu teknolojilerin özümsenmesi ve üzerinde kontrol kurulabilmesi de hava gücünün sunduğu potansiyelden tam manasıyla istifade edilebilmesinin bir diğer ön şartını olarak sivrilmektedir. Hiç de şaşırtıcı olmayan şekilde, bu uzun ve iddialı isterler listesini karşılayabilen devletlerin sayısı hem tarihsel süreçte hem de günümüzde bir elin parmaklarını geçmemektedir.

\section{Summary}

The spectacular successes of aerial operations since the end of Cold War evinced the potential of air power as a war-fighting instrument. In the eyes of the general public, non-scholarly authors and mass media, the 
successes of flying machines in dominating most aspects of modern combat has transformed air power into some kind of miraculous instrument, capable of fulfilling whatever responsibilities are entrusted upon it, irrespective of such restraining factors as the countervailing capabilities of a competent opponent, or geographic circumstances and political objectives of a given conflict. Those grossly exaggerated accounts of air power's virtues, capabilities and potential pass over number of properties fundamental to air power, and its eventual evolution over the course of the last 100 years. A summary overview into the conceptual premises of air power and its historical evolution is necessary in order to filter out those misplaced visions, and rid-off misleading generalizations and clichés pertaining to air power.

Essentially, such scrutinizing validates on the hand that that air power has evolved and matured to become a primary element of modern warfare. However, this observation should not imply that as compared to land and naval forces, air power has finally become the dominant form of military power capable of determining singlehandedly the outcome of military confrontations irrespective of the circumstances of those confrontations. To the contrary, land and naval forces are still indispensable to exploit the advantages and opportunities created by air power and transform them into tactical, strategic and political gains.

A second observation based on historical evolution is that while technological advances have forged ahead, the roles and basic missions of air power have remained essentially the same. The difference lies in the instruments being used, their performance and the degree of effectiveness; hence, technology transformed the way air power's basic missions are executed, but not their basic objectives.

In the same context, a lesson that remains as relevant today as it was a century ago is that the use of air power shall be consistent with the political objectives of such employment, and that those objectives should be realistic and achievable. Grossly magnified and exaggerated appraisals of air power and the miraculous outcomes it is reputed with should therefore be handled and treated with extreme prudence.

Last but not least, quantitative and qualitative superiority in material elements does not always guarantee exploitation of air power's full potential and generate hoped for outcomes. Each conflict has its peculiar 
circumstances facilitating or rendering difficult the use of air power. The success would also depend on the nature and capabilities of the opposing side. Equally, if not more important than air power's material ingredients such as aircraft and munitions, are qualified and well-trained personnel, organizational and intellectual capacity to improvise and implement lessons, and the ability to develop and digest air power's essential technologies. With such demanding tally of requirements, it is hardly surprising that the number of states that could take advantage of air power's full potential has been relatively small.

\section{Çatışma Beyanı:}

Makalenin ile ilgili herhangi bir kurum, kuruluş, kişi ile çıkar çatışması bulunmamaktadır.

\section{Kaynakça \\ Kitaplar}

AKER, F. October 1973: The Arab-Israeli War. Hamden: Archon Books, 1985.

ARMITAGE, M.J. ve Mason, R.A. Air Power in the Nuclear Age. Londra: University of Illinois Press, 1983.

BENBOW, T. British Naval Aviation: The First 100 Years. Surrey: Ashgate, 2011.

BROWN, N. The Future of Air Power. Londra: Croom Helm, 1986.

CLUTTERBUCK, R.L. The Long, Long War: Counter-insurgency in Malaya and Vietnam. Londra: Cassell, 1967.

COX S. ve GRAY P. (ed.). Air Power History: Turning Points from Kitty Hawk to Kosovo. Londra: Frank Cass, 2002.

DOUHET, G. The Command of the Air. (Çev. Dina Ferrari). Alabama: Air UP, 2010.

EARL, E.M. (ed.). Makers of Modern Strategy. Priceton: Princeton UP, 1943.

ERICKSON, E.J. ve UYAR, M. Phase Line Attila. Quantico: Marine Corps UP, 2020.

GATES, D. Sky Wars: A History of Military Aerospace Power. Londra: Reaktion, 2003.

GOOCH, J. (ed.) Air Power: Theory and Practice. Londra: Frank Cass, 1995.

GRAY, P. Air Warfare: History, Theory and Practice. Londra: Bloomsburry, 2016.

GUTTMAN, J. Reconnaissance and Bomber Aircraft Aces of World War 1. Londra: Osprey, 2015.

HIGHAM, R. Air Power: A Concise History. New York: St. Martin's Press, 1972.

HIGHAM, R. Military Intellectuals in Britain 1918-1939. New Brunswick; Rutgers, 1966.

HIGHAM, R. One Hundred Years of Air Power and Aviation. College Station: Texas A\&M UP, 2003.

HURLEY, A.F. Billy Mitchell: Crusader for Air Power. Bloomington: Indiana UP, 1975.

KEANEY, T.A. ve COHEN, A.C. Revolution in Warfare? Air Power in the Persian Gulf. Annapolis: Naval Institute Press, 1995. 
Hava Gücünün Tarihi Gelişimi: Nitelikler, Bileşenler, Görevler ve Etkinlik Açısından Bir Değerlendirme

KEMP, J. Arms and Security: The Egypt-Israel Case. Adeplhi Papers, Say1 52. Londra: IISS, 1968.

LAMBERT, A.P.N. The Psychology of Air Power. RUSI Whitehall Paper Series. Londra: RUSI, 1995.

LAMBETH, B.S. The Transformation of American Air Power. Ithaca: Cornell UP, 2000.

MASON, R.A. (ed.). War in the Third Dimension: Essays in Contemporary Air Power, Londra: Brassey's, 1986.

MASON, T. Air Power: A Centennial Appraisal. Londra: Brassey's, 1994.

Mitchell, W. Winged Defense. Tuscaloosa: University of Alabama Press, 2005.

MÜTERCIMLER, E. Kibrs Harekatımn Bilinmeyen Yönleri. İstanbul: Yaprak Yayınevi, 1990.

OLSEN, J.A. (ed.). A History of Air Warfare. Vassington: Potomac Books, 2010.

PERRET, B. A History of Blitzkrieg. Londra: Robert Hale Ltd, 1983.

STANLEY, R.M. Evolution of Airborne Operations, 1939-1945. E-kitap: Penn \& Sword, 2015. van CREVELD, M. Technology and Warfare. Londra: Brassey's, 1991.

von CLAUSEWITZ, C. On War. 8. Baskı. (Çev. Howard, M. ve Paret, P.), Princeton: Princeton UP, 1984.

WARDEN, J.A. The Air Campaign - Planning for Combat. Vaşington: National Defense UP, 1988.

Kitap Bölümleri, Makaleler, Süreli Yayın Yazıları

BIDDLE, S. "The Libya dilemma: The limits of air power". The Washington Post, 25 Mart 2011.

BIDDLE, T.D. "British and American Approaches to Strategic Bombing". John Gooch (ed.), Air Power: Theory and Practice. Londra: Frank Cass, 1995: 91-144.

BRODIE, B. "Some notes on the evolution of air doctrine". World Politics, Cilt 7, Say1 3, 1955: 349-370.

BYMAN, D.L. ve WAXMAN, M.C. "Kosovo and the Great Air Power Debate". International Security, Cilt 24, Say1 4, 2000: 5-38.

COHEN, E.A. (1993). "The Air War in the Persian Gulf". Armed Forces Fournal International, Haziran 1993: 10-14.

CORUM, J.S. "The Luftwaffe and Lessons Learned in the Spanish Civil War". Sebastian Cox ve Peter Gray (ed.), Air Power History: Turning Points from Kitty Hawk to Kosovo. Londra: Frank Cass, 2002: 66-92.

GARDEN, T. "The Air-Land Battle”. Mason, R.A. (ed.), War in the Third Dimension. Londra: Brassey's, 1986: 149-167.

GEORGE, R.H. "Normandy". Wesley F. Craven ve James L. Cate (eds.), The Army Air Forces in World War II, Volume 3: Europe. Şikago: University of Chicago Press, 1951: 183-227.

GORDON, S.L. "Air Superiority in Israeli-Arab Wars". John A. Olsen (ed.), A history of air warfare. Vaşington: Potomac Books, 2010: 137-166.

HOST, P. "US Air Force plans big investments towards digital architecture and space capabilities". Fane's Defence Weekly, 6 Kasım 2019: 16.

INSINNA, V. "As Force Shrinks, USAF Eyes Ways to Amass Firepower”. Defense News, 11 Temmuz 2016: 16.

JONES, J.F. "Giulio Douhet Vindicated: Desert Strom 1991". Naval War College Review, Cilt 45, Say1 1, 1992: 97-101.

STEPHENS, A. "The Air War in Korea". John A. Olsen (ed.), A history of warfare. Vaşington: Potomac Books, 2010: 85-106.

SWEETMAN, B. "Catching up with doctrine". Fane's Defence Weekly. 29 Haziran 1991: 1174-1176.

THOMPSON, W. "Operations Over Vietnam". John A. Olsen (ed.), A history of air warfare. Vaşington: Potomac Books, 2010: 107-126. 
WARNER, E. "Douhet, Mitchell, Seversky: Theories of Air Warfare". Edward M. Earl (ed.), Makers of Modern Strategy. Princeton: Princeton UP, 1943: 485-503.

WATSON, D.E. "Rethinking the US Nuclear Triad". Strategic Studies Quarterly. Cilt 11, Say1 4, 2017: 134-150.

ZAKHEIM, D.S. "The South Atlantic: Evaluating the Lessons". Brown, J. ve Snyder, W.P. (ed.), The Regionalization of Warfare. New Jersey: Transaction Books, 1985: 37-54. Internet Makaleleri

BENITEZ, M. ve PIETRUCHA, M. "Political Airpower, Part II: The Seductive Allure of Precision Weapons". War on the Rocks, 30 Kasim 2016.

COOPER, T. "Here's the Key to Understand the Russian Air Force's Actions in Syria”. War Is Boring. 6 Haziran 2016.

DALSJÖ, R. vd. Bursting the Bubble: Russian A2/AD in the Baltic Region, Stockholm: FOI, 2019.

"Experience of Air Power in Libya". Pathfinder - Air Power Development Centre Bulletin, Say1 152, 2011.

GROLL, E. ve GRAMER, R. "How the U.S. Miscounted the Dead in Syria". Foreign Policy, 25 Nisan 2019.

JACKSON, M. vd. "Modern Siege Warfare: How It Is Changing Counterinsurgency". Foreign Affairs, 7 Aralik 2016.

KASAPOGLU, C. "Turkey's Drone Blitz Over Idlib”. Terrorism Monitor, Cilt 18, Say1 8, 2020.

NICHOLSON, D. "Foreign drones turning the tide in Libya". Defence Connect, 4 Haziran 2020.

PIETRRUCHA, M.ve REKNEN, J. "Air Power May Not Win Wars, But It Sure Doesn't Lose Them". War on the Rocks, 19 Ağustos 2015.

RIPLEY, T. “Air Power Vindicated”, Flight International, 1 Kasım 1995.

SALACANIN, S. "What is behind Saudi military failures?", Middle East Monitor, 10 Ekim 2019.

SCHNEIDER, J. ve MACDONALD, J. "Why Troops Don't Trust Drones", Foreign Affairs, 20 Aralık 2017.

\section{Raporlar}

Basic Aerospace Doctrine of the United States Air Force. Air Force Manual 1-1, Vol. 1. Vaşington: Department of Air Force, 1992.

Operation Desert Strom Air War. Letter Report by General Accounting Office. Vaşington: GOA, 1996. 